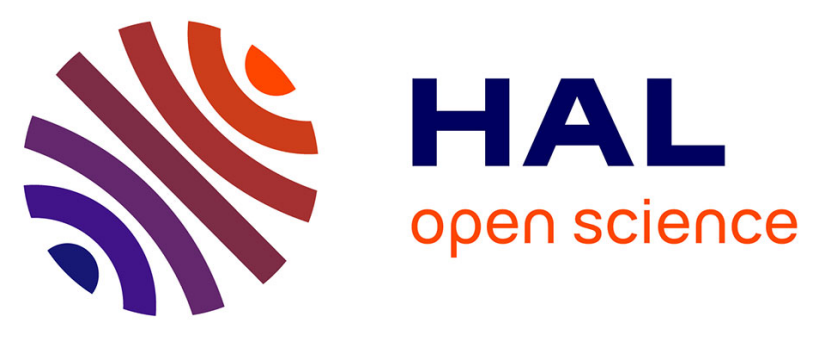

\title{
New chronological constraints on intense Holocene eruptions and landslide activity at Tacaná volcanic complex (Mexico)
}

\author{
Jesús Alcalá-Reygosa, José Luis Arce, José Luis Macías, Irene
}

Schimmelpfennig, Ricardo Saucedo, Juan Manuel Sánchez, Teodoro Carlón, Rosario Vázquez, Guillermo Cisneros-Máximo, Adrian Jímenez, et al.

\section{To cite this version:}

Jesús Alcalá-Reygosa, José Luis Arce, José Luis Macías, Irene Schimmelpfennig, Ricardo Saucedo, et al.. New chronological constraints on intense Holocene eruptions and landslide activity at Tacaná volcanic complex (Mexico). Quaternary Geochronology, 2021, 65, pp.101183. 10.1016/j.quageo.2021.101183 . hal-03226096

\section{HAL Id: hal-03226096 https://hal.science/hal-03226096}

Submitted on 14 May 2021

HAL is a multi-disciplinary open access archive for the deposit and dissemination of scientific research documents, whether they are published or not. The documents may come from teaching and research institutions in France or abroad, or from public or private research centers.
L'archive ouverte pluridisciplinaire HAL, est destinée au dépôt et à la diffusion de documents scientifiques de niveau recherche, publiés ou non, émanant des établissements d'enseignement et de recherche français ou étrangers, des laboratoires publics ou privés. 


\section{Journal Pre-proof}

New chronological constraints on intense Holocene eruptions and landslide activity at Tacana volcanic complex (Mexico)

Jesús Alcalá-Reygosa, José Luis Arce, José Luis Macías, Irene Schimmelpfennig, Ricardo Saucedo, Juan Manuel Sánchez, Teodoro Carlón, Rosario Vázquez, Guillermo Cisneros-Máximo, Adrian Jímenez, Salvador Fernández, Aster Team

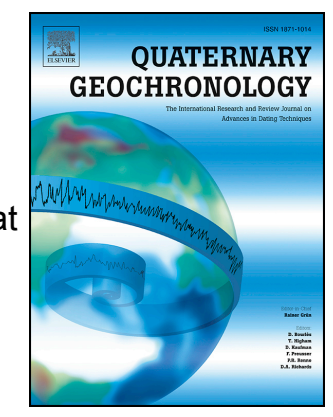

PII: S1871-1014(21)00034-0

DOI: https://doi.org/10.1016/j.quageo.2021.101183

Reference: QUAGEO 101183

To appear in: Quaternary Geochronology

Received Date: 8 June 2020

Revised Date: 10 April 2021

Accepted Date: 11 April 2021

Please cite this article as: Alcalá-Reygosa, Jesú., Arce, José.Luis., Macías, José.Luis., Schimmelpfennig, I., Saucedo, R., Sánchez, J.M., Carlón, T., Vázquez, R., Cisneros-Máximo, G., Jímenez, A., Fernández, S., Team, A., New chronological constraints on intense Holocene eruptions and landslide activity at Tacana volcanic complex (Mexico), Quaternary Geochronology (2021), doi: https://doi.org/10.1016/j.quageo.2021.101183.

This is a PDF file of an article that has undergone enhancements after acceptance, such as the addition of a cover page and metadata, and formatting for readability, but it is not yet the definitive version of record. This version will undergo additional copyediting, typesetting and review before it is published in its final form, but we are providing this version to give early visibility of the article. Please note that, during the production process, errors may be discovered which could affect the content, and all legal disclaimers that apply to the journal pertain.

(c) 2021 Published by Elsevier B.V. 
NEW CHRONOLOGICAL CONSTRAINTS ON INTENSE HOLOCENE

ERUPTIONS AND LANDSLIDE ACTIVITY AT TACANA VOLCANIC COMPLEX

(MEXICO)

Jesús Alcalá-Reygosa ${ }^{\mathrm{a}}$, José Luis Arce ${ }^{\mathrm{b}}$, José Luis Macías ${ }^{\mathrm{c}}$, Irene Schimmelpfennig ${ }^{\mathrm{d}}$, Ricardo Saucedo ${ }^{\mathrm{e}}$, Juan Manuel Sánchez ${ }^{\mathrm{f}}$, Teodoro Carlón ${ }^{\mathrm{c}}$, Rosario Vázquez ${ }^{\mathrm{g}}$, Guillermo Cisneros-Máximo c ${ }^{\text {, Adrian Jímenez }}{ }^{\mathrm{h}}$, Salvador Fernández ${ }^{\text {, and ASTER Team }}{ }^{\mathrm{d}, \mathrm{i}}$

${ }^{a}$ Facultad de Filosofía y Letras, Universidad Nacional Autónoma de México, Ciudad Universitaria, 04510, Ciudad de México, Mexico. Corresponding author: jalcalar@ucm.es

b Instituto de Geología, Universidad Nacional Autónoma de México, Coyoacán, 04510, Ciudad de México, Mexico

${ }^{\mathrm{c}}$ Instituto de Geofísica, Universidad Nacional Autónoma de México, Antigua Carretera a Pátzcuaro 8701, 58190, Morelia, Michoacán, Mexico

${ }^{\mathrm{f}}$ Instituto Politécnico Nacional-CIIEMAD, Miguel Othón de Mendizábal s/n. Col. La Escalera, C.P. 07320, Del. Gustavo A. Madero, Ciudad de México, Mexico

${ }^{\mathrm{g}}$ Escuela Nacional de Estudios Superiores (ENES-Juriquilla), Universidad Nacional Autónoma de Méxic, Campus UNAM Blvd. Juriquilla 3001, Juriquilla, Querétaro, México

${ }^{\text {h }}$ Escuela Nacional de Estudios Superiores (ENES-Morelia), Universidad Nacional Autónoma de México, Antigua Carretera a Pátzcuaro 8701, 58190, Morelia, Michoacán, Mexico

${ }^{\mathrm{i}}$ Consortium: Georges Aumaître, Didier Bourlès, Karim Keddadouche 
Usual methods are unfortunately unsuitable to accurately date many Holocene deposits and landforms from active Mexican volcanoes. This is notably the case for the Tacaná Volcanic

44 Complex (TVC), located in the State of Chiapas in southern Mexico, and the San Marcos Department in Guatemala. The complex consists of the Chichuj, Tacaná, and San Antonio volcanoes and the Ardillas dome. Tacaná volcano, the main summit of the TVC, collapsed $15 \pm 5$ ka ago $\left({ }^{40} \mathrm{Ar} /{ }^{39} \mathrm{Ar}\right)$, producing the Agua Caliente Debris Avalanche. The result was the formation of a horseshoe-shaped crater $600 \mathrm{~m}$ wide open to the northwest. Afterward, several undated effusive and explosive eruptions occurred. All these eruptions are likely Late Pleistocene to Holocene in age because the landforms derived of that activity overlap the horseshoe-shaped crater. To corroborate this hypothesis, we used surface exposure dating with in situ-produced cosmogenic ${ }^{36} \mathrm{Cl}$ combined with lichenometry and dendrochronology in the summit domes, the Ardillas dome, the horseshoeshaped crater's cliff, and a lava. The ${ }^{36} \mathrm{Cl}$ exposure ages $(9.3 \pm 1.9 \mathrm{ka} ; 8.9 \pm 0.9 \mathrm{ka} ; 8.6 \pm 1.7 \mathrm{ka})$ of the summit domes are statistically indistinguishable within the associated uncertainties and suggest that the domes formed during Early Holocene. Instead, the southern part of the Late Pleistocene collapsed crater yielded significantly younger ages ranging from $5.3 \pm 0.6$ to $7.0 \pm 0.8 \mathrm{ka}$. These ages are assumed to be minimum and might indicate later rockfall activity and instability, affecting the horseshoe-shaped crater. The ${ }^{36} \mathrm{Cl}$ exposure age of an andesitic lava $(0.4 \pm 0.1 \mathrm{ka})$, emplaced to the SW of Tacaná, is in good agreement with lichenometry (> $347 \mathrm{yr}$ ). These ages could represent a gravitational collapse event associated with phreatic explosions vented close to a scar collapse. The

$61{ }^{36} \mathrm{Cl}$ exposure ages derived from the Ardillas lava dome $(0.3 \pm 0.1 \mathrm{ka})$ do not correspond to its 62 emplacement age. The dome must be older than pyroclastic deposits dated at $760 \pm 30 \mathrm{yr} \mathrm{BP}\left({ }^{14} \mathrm{C}\right)$ 63 that cover its surface. Strikingly, the ${ }^{36} \mathrm{Cl}$, lichenometrical and dendrochronological data of the 64 "Andesitic" lava and the Ardillas dome are associated with NE-SW landslide scars, explosion 65 craters, phreatic vents, fumarolic activity, and tensional fractures. All these features are perpendicular to the NW-SE minimum stress regime ( $\sigma 3)$, affecting the TVC and generating gravitational activity. Nowadays, gravitational collapses represent a real threat to the surrounding populations that can be triggered not only by volcanic activity but also by seismicity and extraordinary rains.

71 Key words: Tacaná, México, in situ-produced cosmogenic ${ }^{36} \mathrm{Cl}$ dating, lichenometry, 72 dendrochronology, Holocene. 


\section{Introduction}

Mexican volcanoes have experienced intensive activity during the Holocene, especially in the Trans-Mexican Volcanic Belt, the Chiapanecan Volcanic Arc, the northwestern edge of the Central American Volcanic Arc, Baja California (San Quintin volcanic fields), el Pinacate Volcanic Field (NW Mexico) and the Revillagigedo Archipelago (700 km west of Manzanillo city). Roughly 153 well-constrained Holocene eruptions have been reported of which $63 \%$ were produced on active stratovolcanoes and calderas and $37 \%$ in monogenetic volcanic fields (Macías and Arce, 2019). To constrain the chronology of these eruptions,

83 several dating methods such as radiocarbon, ${ }^{40} \mathrm{Ar} /{ }^{39} \mathrm{Ar},{ }^{230} \mathrm{U}-\mathrm{Th}$ in zircons, paleomagnetism

84 and in situ-produced cosmogenic ${ }^{36} \mathrm{Cl}$ and ${ }^{10} \mathrm{Be}$ have been used (Macías and Arce, 2019).

85 However, many deposits and landforms remain undated, resulting in limitations in the

86 chronological records that prevent establishing highly-resolved histories of volcanic activity to anticipate future eruptions and assess the potential risks for neighboring populations. Such limitations are encountered for Tacaná Volcanic Complex (TVC), located in the State of Chiapas in southern Mexico and the San Marcos Department in

90 Guatemala. Today, more than 300,000 inhabitants live within a $35 \mathrm{~km}$ radius of the summit, 91 placing the TVC as the second most hazardous volcano in Mexico, just after Popocatépetl.

93 A phreatic explosion occurred at the TVC in 1986 after which it has been considered an 94 active volcano in a quiescent state. The main crater of Tacaná volcano has a horseshoe95 shaped crater associated with a collapse event that occurred $15 \pm 5 \mathrm{ka}\left({ }^{40} \mathrm{Ar} /{ }^{39} \mathrm{Ar}\right)$ that 96 dispersed the Agua Caliente debris avalanche deposit (Macías et al., 2010). One of the 97 andesitic lavas (Agua Zarca) erupted $12 \pm 5 \mathrm{ka}\left({ }^{40} \mathrm{Ar} /{ }^{39} \mathrm{Ar}\right)$ from the collapsed crater and 98 covered the debris avalanche (Macías et al. 2010). These ages are associated with large 99 uncertainties and therefore only provide an approximate chronology of the respective 100 events and tentatively bracket the volcano's subsequent activity. Besides, little is known 101 about its activity over the Holocene, especially the effusive activity, with several summit 
102 landforms (i.e. domes, lavas) of unknown age. Here, we date four lava domes (three from

103 the Tacaná summit informally dubbed "East", "Northwest" and "Southwest", and the

104 Ardillas dome), the cliff of the horseshoe-shaped crater and a lava (informally named

105 "Andesitic lava") extruded from the summit of Tacaná. We hypothesized that all these

106 landforms have a Late Pleistocene- Holocene age because they overlap the horseshoe-

107 shaped crater dated at $15 \pm 5 \mathrm{ka}\left({ }^{40} \mathrm{Ar} /{ }^{39} \mathrm{Ar}\right)$. To confirm this hypothesis, we collected

108 eighteen samples from $5 \mathrm{~cm}$ flat-topped solid andesitic surface rocks for exposure dating

109 with in situ-produced cosmogenic ${ }^{36} \mathrm{Cl}$ (cosmic ray exposure; ${ }^{36} \mathrm{Cl} \mathrm{CRE}$ hereafter) combined

110 with lichenometry and dendrochronology (Ardillas dome and the "Andesitic lava"). The

111 latter two methods provided minimum ages of the sampled rocks. To understand the

112 volcanic evolution of the TVC, we generated a geologic map and stratigraphy of the

113 summit area aided by new structural data. Finally, we performed whole-rock chemistry of

114 all samples to define their chemical composition and evolution of the summit structures.

2. Study area and previous work at Tacaná Volcanic Complex (TVC)

118 The TVC is part of the northwestern end of the Central American Volcanic Arc (Fig. 1A).

119 The complex is constituted by four NE-SW aligned volcanic structures called Chichuj,

120 Tacaná, Ardillas Dome, and San Antonio (Fig. 1B) (García-Palomo et al., 2006). It was

121 built on Mesozoic metamorphic and Tertiary intrusive rocks (150 Ma and 35-13 Ma

122 respectively), and deposits from mid-Pleistocene calderas (1-2 Ma) (Garduño-Monroy et

123 al., 2015). The complex is affected by three fault systems, which are from older to younger:

124 NW-SE striking fractures and faults that cut the methamorphic and intrusive basement, NE-

125 striking faults parallel to the TVC, and the N-S striking youngest faults that are 126 superimposed on the others (García-Palomo et al., 2006). The NE-SW fault system delimits 127 the Tacaná graben that has controlled the emplacement and evolution of the Chichuj, 128 Tacaná, and San Antonio volcanoes and the Las Ardillas dome structures, as well as the 129 emplacement of Sibinal and San Rafel calderas (Fig. 1B). A linear regression of the 130 alignment of these structures showed an adjustment with a correlation coefficient (r) of 
1310.91 , indicating that their location is controlled by $\mathrm{N}^{\circ} 5^{\circ} \mathrm{E}$ orientation fissures defined by a 132 minimum stress $\left(\sigma_{3}\right)$ with a $\mathrm{N} 53^{\circ} \mathrm{W}$ orientation (García-Palomo et al., 2006; Macías et al., 133 2010).

134
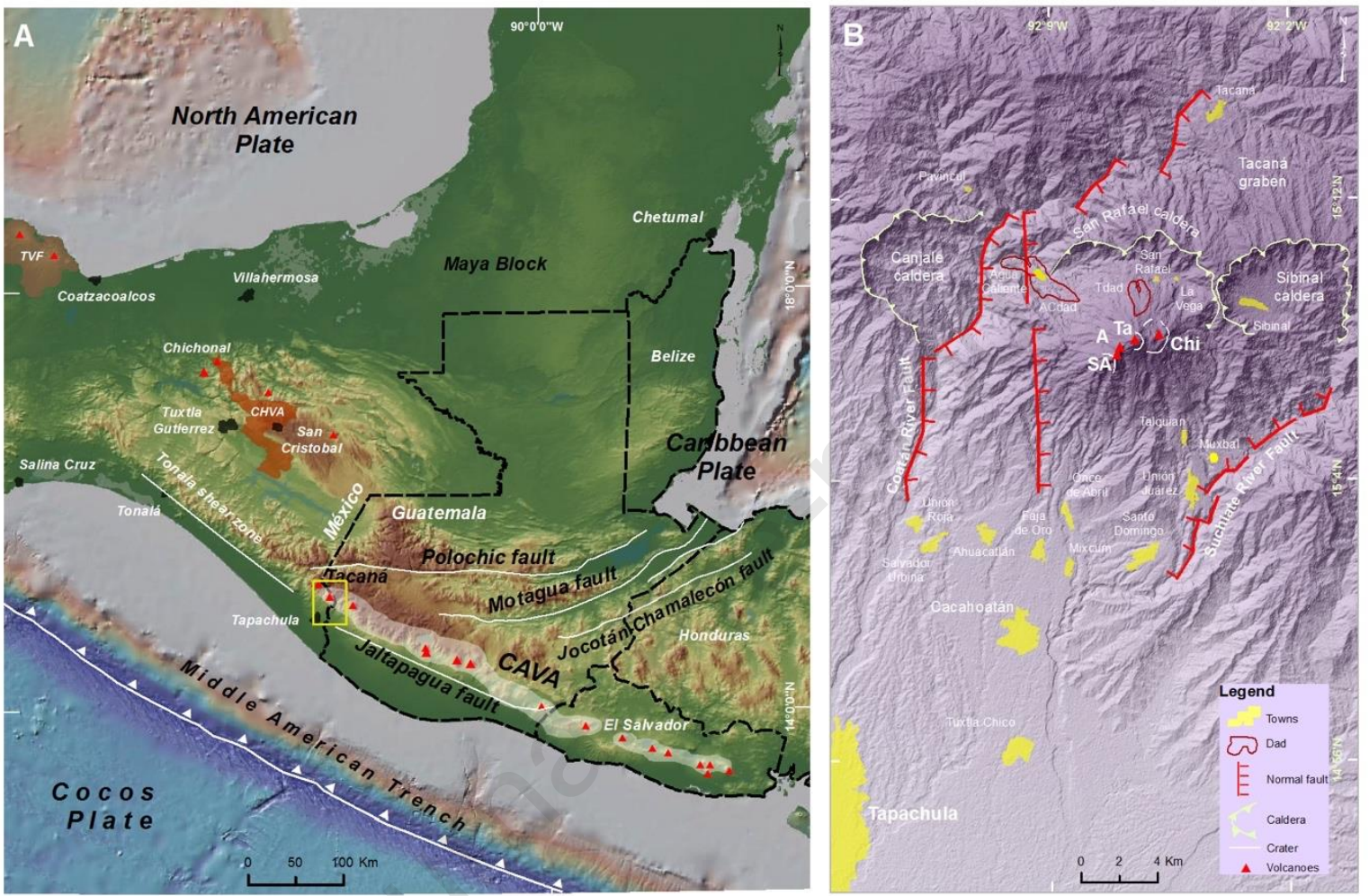

Figure 1. (A) Map showing the tectonic context of southern Mexico and the location of the Tacaná volcanic complex (TVC) (yellow rectangle). Abbreviations: CAVA, Central American Volcanic Arc; TVF, Tuxtlas Volcanic Field; CHVA, Chiapanecan Volcanic Arc. (B) Detailed Digital Elevation Model of the TVC. Abbreviations: Chi (Chichuj), Ta (Tacaná), A (Ardillas dome) and SA (San Antonio) volcanoes; ACdad (Debris Avalanche Deposits of Agua Caliente) and Tdad (Debris Avalanche Deposits of Tuimanj). Main fault systems are displayed in red.

Volcanic activity in the TVC started ca. $300 \mathrm{ka}$ ago with the emplacement of Chichuj volcano, followed by the emplacement of Tacaná structure around 40 ka (LimónHernández, 2011), and San Antonio volcano some ca. 20 ka. Finally, a lava dome defined as Ardillas (>800 yr) was emitted between San Antonio and Tacaná edifices. Since its formation, the TVC has produced several types of eruptions such as sector collapse (Macías et al., 2010), Peléean (Macías et al., 2000), Plinian and subplinian events (Arce et al., 
150 2012), and intense effusive activity (Limón-Hernández, 2011). As mentioned before, the

151 Tacaná summit has a $600 \mathrm{~m}$ wide horseshoe-shaped crater open to the northwest. This

152 crater was produced by a collapse $15 \pm 5 \mathrm{ka}$ ago $\left({ }^{40} \mathrm{Ar} /{ }^{39} \mathrm{Ar}\right)$ followed by the emplacement

153 of the Agua Caliente debris avalanche (Macías et al., 2010).

155 After the collapse, intense effusive activity took place inside the horseshoe-shaped crater 156 through the emission of several lava flows to the NW. One of these lavas called Agua Zarca 157 was dated at $12 \pm 5 \mathrm{ka}\left({ }^{40} \mathrm{Ar} /{ }^{39} \mathrm{Ar}\right.$ ) (Macías et al. 2010). Subsequent lava emissions infilled 158 the horseshoe-shaped crater and extruded the three bulb-like domes ("East", "Northwest", 159 and "Southwest") at the summit of Tacaná (Figs. 2 and 3). Prior or during the first stages of 160 the extrusion of these domes, an olivine-bearing lava flow was emitted to the southwest of 161 Tacaná (green dashed line in Fig. 2). Another lava of andesitic composition was emitted to 162 the southwest between the ca. 15 ka horseshoe-shaped crater and the Ardillas Dome (red 163 dashed line in Fig. 2). These lavas and associated domes have not been dated yet and 164 therefore their relationship with the TVC Holocene eruptive stratigraphy has not been 165 determined. As revealed by stratigraphy and radiocarbon dating, at the beginning of the 166 Holocene an explosive eruption called Once de Abril disrupted the summit of Tacaná, 167 dispersing dense and dilute Pyroclastic Density Currents (PDCs) that swept the volcano 168 flanks beyond the break in slope (Macías et al., 2015). Around the same time, the northern 169 part of Tacaná collapsed producing the Tuimanj debris avalanche towards Guatemala 170 (Limón-Hernández, 2011). Since then, the TVC has generated at least nine radiocarbon 171 dated smaller eruptions that have dispersed pyroclastic deposits on the middle and upper 172 flanks of the complex dated at ca. 7.6, ca. 6.1-5.6, ca. 2.6, ca. 1.9, ca. 0.9, ca. 0.8, ca. 0.37, 173 ca. 0.28 , and ca. $0.15 \mathrm{ka}$ (Macías et al., 2015). 


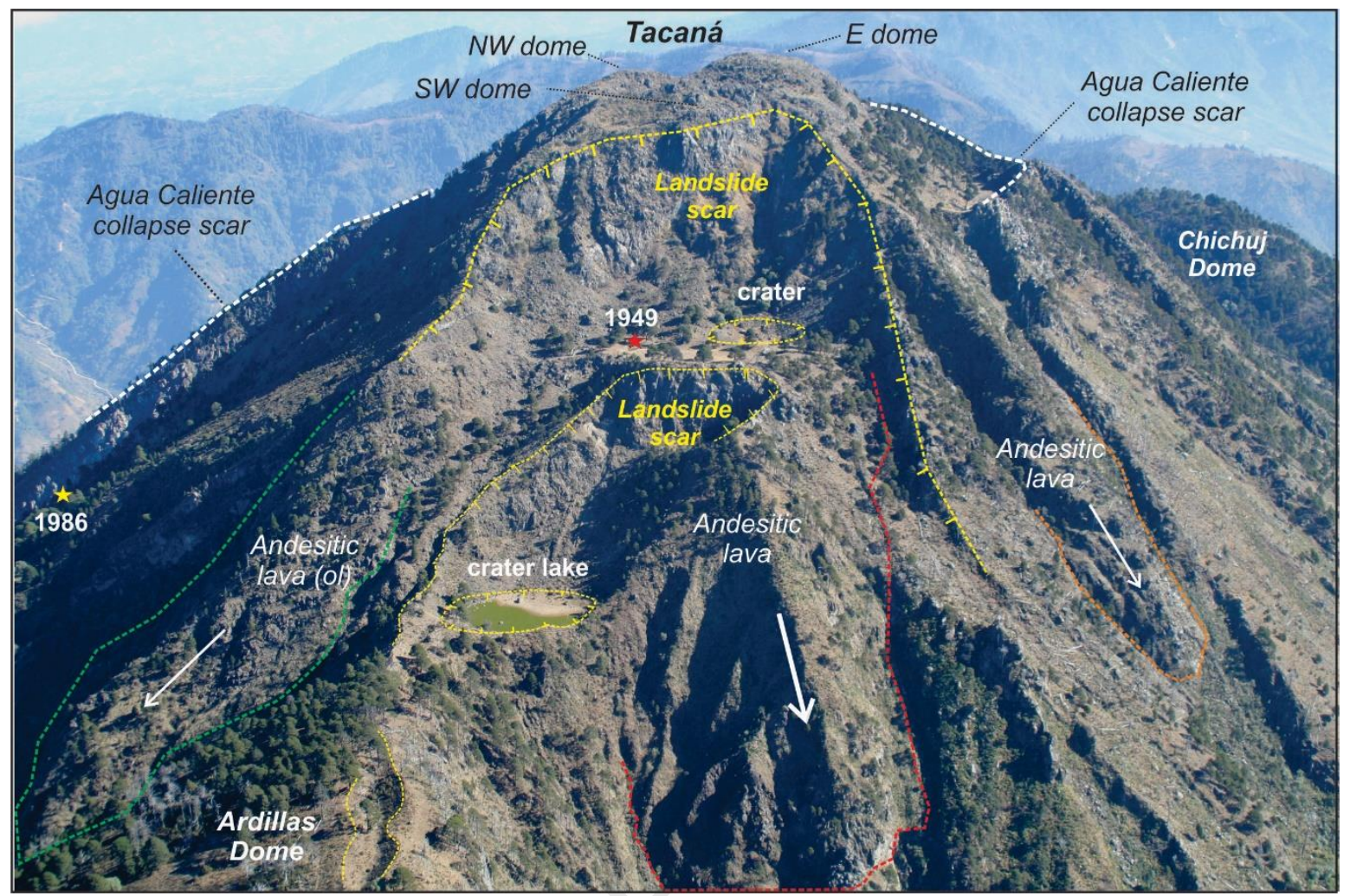

Figure 2. Aerial view from the southwest of the TVC, showing the summit of Tacaná volcano. Notice the Agua Caliente collapse scar (ca. $15 \mathrm{ka}$ ), two explosion craters, and two landslide scars 181 (yellow dashed lines). The stars point out the locations of the 1949 (red) and 1986 (yellow) phreatic

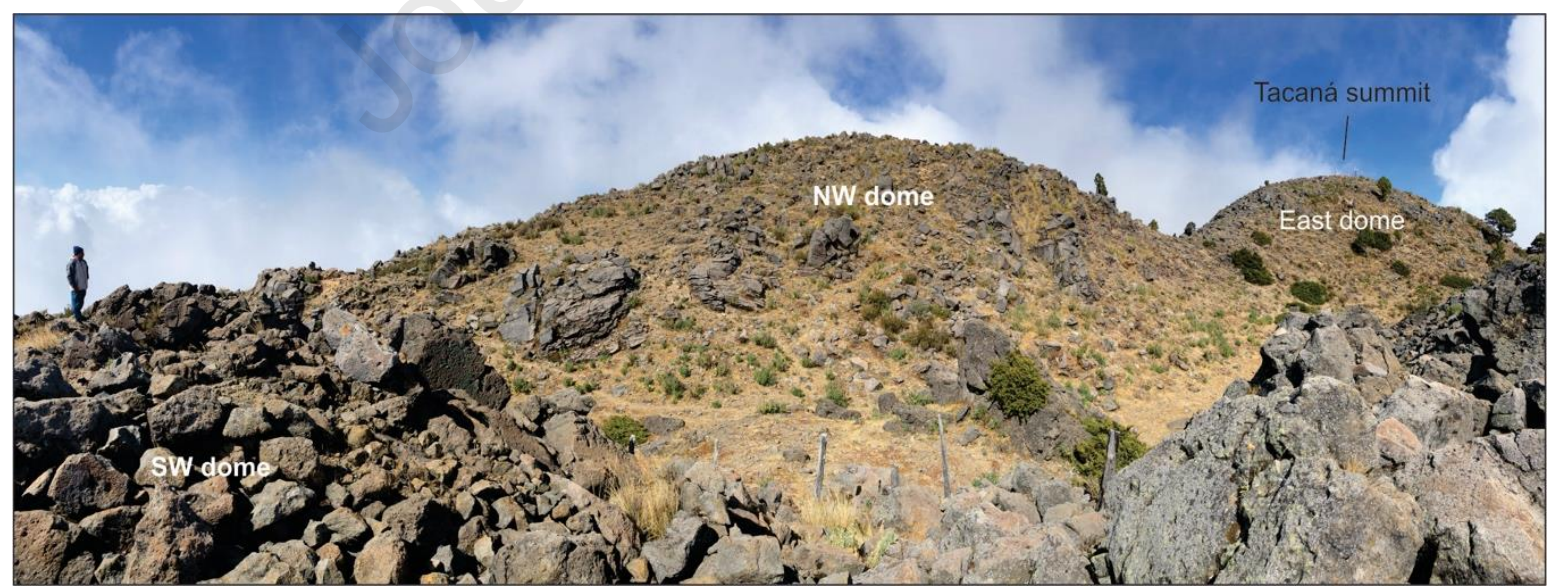

185 Figure 3. Detailed photograph of East, Northwestern and Southwestern lava domes from the summit 186 of Tacaná volcano. 
188 The precise source of these eruptions is not known yet because the summit has been

189 modified by neotectonics and mass wasting processes. In fact, two NE-SW landslide scars

190 can be recognized at Tacaná (Figs. 2 and 4), one of them is $350 \mathrm{~m}$ wide and affects the

191 summit domes; and the second one is $60 \mathrm{~m}$ wide and affects the "Andesitic lava" located

192 between the Ardillas dome and the horseshoe-shaped crater, southwest of the summit.

193 Another two NW-SE collapses affect the northwestern part of the Tacaná cone. At least two

194 of the Late Holocene eruptions have occurred along the NE-SW fractures between Tacaná

195 and Las Ardillas dome (Fig. 4). A phreatomagmatic eruption at $760 \pm 30$ yr cal BP

196 dispersed dilute PDCs and ash fallouts generating a 80 × $60 \mathrm{~m}$ wide crater that today

197 contains a greenish lake (Macías et al., 2018). Northeast of this crater lake, at the base of

198 the largest NE-SW scar, another explosion crater vented on top of the "Andesitic lava".

199 This $60 \times 25 \mathrm{~m}$ wide crater is made of around $5 \mathrm{~m}$ thick breccia interbedded with

200 discontinuous pyroclastic deposits (Fig. 2). The 1949 phreatic explosion of Tacaná

201 (Mülleried, 1951) was vented between these two explosion craters and along the NE-SW

202 fractures.

203

204 In 1986, Tacaná resumed activity with another phreatic explosion at the base of a lava cliff,

205 which had formed during the ca.15 ka collapse of Tacaná (Fig. 2). This explosion attracted

206 the attention of scientists (Martini et al., 1987; De la Cruz-Reyna et al., 1989) leading to the

207 discovery of past eruptions (Espíndola et al., 1989) and rise up the awareness of the danger

208 that the volcano represented to the surrounding communities. As a consequence, Mercado

209 and Rose (1992) presented the first general hazards map and mentioned historic reports of

210 another eruption that had occurred around 1855-1856. This eruption has recently been

211 related with the suppression of tree-ring growth between 1857 and 1868 (Carlón et al.,

212 2020).

213

214 Today, the TVC shows signs of volcanic activity with fumaroles on the northwestern flank

215 of San Antonio volcano and thermal springs and fumaroles output on the northwestern

216 flank of Tacaná, which reach as far as the village of Agua Caliente (Rouwet et al., 2004; 
217 2009). On top of the Tacaná summit domes ("East", "Northwest" and "Southwest"), a

218 paleosol is covered by the 1902 ash fall deposits of Santa Maria volcano, Guatemala

219 (Williams and Self, 1983).

220
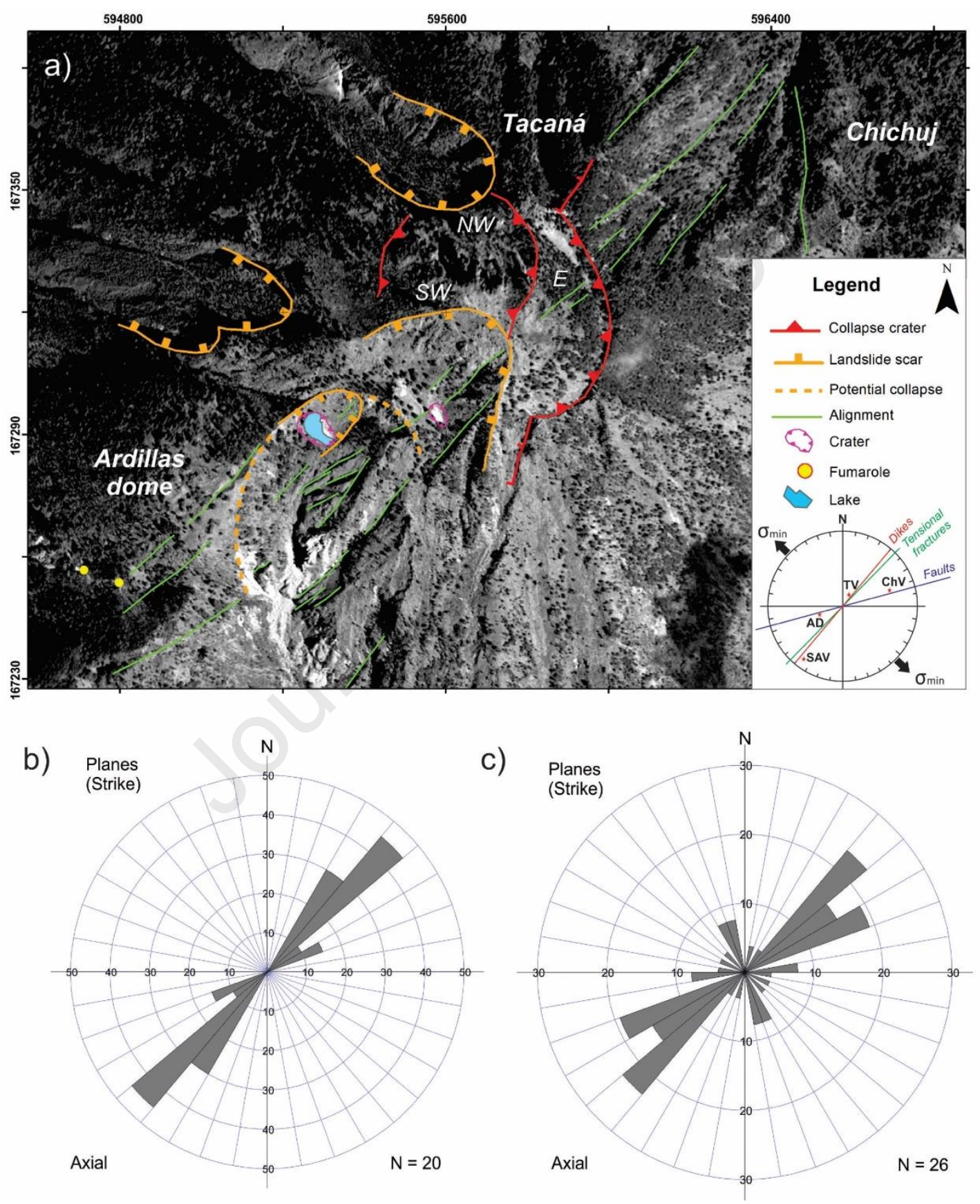

222 Figure 4. a) Structural map of the TVC summit, b) Rose diagram obtained from the SPOT 7 image 223 and the DEM; c) Rose fracture of the data collected along the NE-SW fracture on top of the San 224 Antonio dome. Dome abbreviations are: $\mathrm{E}=$ Eastern, NW = Northwestern, and SW = Southwestern. 
225

226

227

228

229

230

231

232

233

234

235

236

237

238

239

240

241

242

243

244

245

246

\section{7}

248

249

250

251

252

253

254

255

256

\section{Methods}

\subsection{Stratigraphical and structural analyses}

The stratigraphic and structural analyses of the area were carried out with a SPOT 7 satellite image, a high resolution Digital Elevation Model (5 m resolution), two Digital Elevation Model (12.5 m resolution, Alospolar, NASA; and $100 \mathrm{~m}$ resolution, GeoMapApp.org), and the collection of field data gathered during 2018 and 2019 (Fig. 4a). In specific locations, stratigraphic sections were reconstructed and samples were collected for different analysis.

\subsection{Whole-rock chemistry}

In this paper, six new chemical analyses for Tacaná summit domes and lavas are reported. Samples were cleaned and washed, then pulverized with a stainless steel mortar. Powder samples were analyzed by the X-ray Fluorescence (XRF) method at Service d'Analyse des Roches et des Minéraux (SARM, CRPG, Nancy, France), major elements by ICP-OES, and trace elements by ICP-MS except $\mathrm{Cl}$ (spectrophotometry), B (colorimetry) and $\mathrm{Li}$ (atomic absorption). Loss on ignition (LOI) was determined for all analyzed samples, for which 1 gram of powder was heated at $1000^{\circ} \mathrm{C}$ for one hour and then reweighed.

\subsection{Lichenometry}

Lichenometry used in this study provides a minimum age of the "Andesitic lava" and the Ardillas dome. The largest diameter of the biggest circular thalli of Rhizocarpon geographicum located on well preserved protruding features with smooth surfaces were measured using a Bernier calibrator. Digital photographs of the lichen were taken, using a scale (one peso coin of $21 \mathrm{~mm}$ of diameter). The age of the largest lichen was determined applying the growth rate of $0.23 \mathrm{~mm} \mathrm{a}^{-1}$ for Rhizocarpon geographicum constrained on Iztaccíhuatl volcano, situated ca. $900 \mathrm{~km}$ to the northwest of the TVC (Palacios et al., 2012). Despite the distance, the measurement sites of the lichen are located at a similar 
257

258

259

260

261

262

263

264

265

266

267

268

269

270

271

272

273

274

275

276

277

278

279

280

281

282

283

284

285

286

287

288

289

altitude $(\sim 4,000-4,500 \mathrm{~m}$ a.s.1.), and climate at that altitudinal range is not significantly different on both volcanoes.

\subsection{Dendrochronological sampling and sample processing}

Dendrochronological samples were collected from Pinus hartwegii Lindl (9 samples) and Juniperus monticola (1 sample) on the summits of the Tacaná volcano and Ardillas dome in the years 2017 and 2019. No samples of trees were collected on the "Andesitic lava", because continuous landslides limit their colonization. The sampled trees were located at elevations ranging from 3400 to $4040 \mathrm{~m}$. The sampling consisted in extracting two or three increment cores from each tree using a Häglof borer (10 mm diameter; Häglof Sweden AB, Långsele, Västernorrland, Sweden) perpendicular to the stem and at breast height $(1.30 \mathrm{~m})$. Then, 10 trees were drilled for a total sampling set of 22 increment cores. Increment cores were processed using sandpaper with progressive grain sizes from 80 to 1200 grains $\cdot \mathrm{cm}^{-2}$ according to standard dendrochronological techniques (Stokes and Smiley, 1996). Once the annual rings were visible, growth rings were counted from the pit to the bark under the microscope.

\subsection{Cosmic ray exposure dating with ${ }^{36} \mathrm{Cl}$}

In Mexico, CRE dating has been previously used to determine the age of lavas (VázquezSelem and Heine, 2011; Alcalá-Reygosa et al., 2018 a, b) and domes (Arce et al., 2003) in stratovolcanoes and monogenetic edifices. CRE dating relies on the interaction of cosmic ray derived particles with certain target elements of the rocks. ${ }^{36} \mathrm{Cl}$ can be extracted from any mineral phase and rock type that contains one or more of its most important target elements, i.e. $\mathrm{Ca}, \mathrm{K}$ and $\mathrm{Cl}$ (Dunai, 2010). Moreover, it has been recently demonstrated that

${ }^{36} \mathrm{Cl}$ dating provides surface exposure ages of volcanic rocks of as young as a few hundred years (Jomelli et al., 2016).

\subsubsection{Sampling and physical treatment of the samples}

Eighteen samples (Tac 1 - Tac 18) were taken with hammer and chisel from the $5 \mathrm{~cm}$ flattopped solid rock surfaces (Table 1). Twelve of them were collected on the "East", "Northwest" and "Southwest" Tacaná domes (Tac 1 - Tac 9) and the Ardillas dome (Tac 13 - Tac 15). Three samples were taken from the limit of the steep cliff of the horseshoe- 
290 shaped crater (Tac 10 - Tac 12) and another three come from the "Andesitic lava" located

291 to the southwest of this crater (Tac 16 - Tac 18). All the samples were collected from well-

292 preserved surfaces without evidence of erosion, weathering or boulder toppling to minimize

293 potential bias in the ${ }^{36} \mathrm{Cl}$ surface concentrations, which accumulated during exposure to

294 cosmic rays since formation of the sampled surfaces (Alcalá-Reygosa et al., 2018a).

295 Furthermore, samples were collected from protruding geometries to minimize the effects of

296 surface shielding by pyroclastic layers and soils. The geographic coordinates were obtained

297 with Garmin GPS, and the topographic shielding was determined with compass and

298 clinometer. It must be noted that the samples taken from the steep cliff of the horseshoe-

299 shaped crater, Las Ardillas dome and the "Andesitic lava" represented a challenge due to

300 active gravitational processes, neotectonics and slope instability, which could compromise

\begin{tabular}{|c|c|c|c|c|c|c|c|c|}
\hline \multirow{6}{*}{$\begin{array}{l}\text { plan } \\
\text { the }\end{array}$} & \multirow{6}{*}{$\begin{array}{r}\text { to } \\
\text { ages }\end{array}$} & Sample & $\begin{array}{l}\text { Latitude } \\
\left({ }^{\circ} \mathrm{N}\right)\end{array}$ & $\begin{array}{c}\text { Longitude } \\
\left({ }^{\circ} \mathrm{W}\right)\end{array}$ & $\begin{array}{l}\text { Altitude } \\
\text { (m.a.s.l) }\end{array}$ & $\begin{array}{c}\text { Thickness } \\
(\mathrm{cm})\end{array}$ & $\begin{array}{c}\text { Shielding } \\
\text { factor }\end{array}$ & \multirow{6}{*}{ of } \\
\hline & & Tac 1 & 15.13 & -92.10 & 4086 & 2.0 & 0.98665 & \\
\hline & & Tac 2 & 15.13 & -92.10 & 4097 & 2.0 & 0.99343 & \\
\hline & & Tac 3 & 15.13 & -92.10 & 4102 & 2.5 & 0.97627 & \\
\hline & & Tac 4 & 15.13 & -92.10 & 4081 & 4.0 & 0.99637 & \\
\hline & & Tac 5 & 15.13 & -92.10 & 4088 & 2.0 & 0.99718 & \\
\hline
\end{tabular}

304 landforms. 
305

306

307

308

309

310

311

312

313

314

315

316

317

318

$\begin{array}{ccc}\text { Tac } 6 & 15.13 & -92.10 \\ \text { Tac } 7 & 15.13 & -92.10 \\ \text { Tac } 8 & 15.13 & -92.10 \\ \text { Tac 9 } & 15.13 & -92.10 \\ \text { Tac 10 } & 15.13 & -92.10 \\ \text { Tac 11 } & 15.13 & -92.10 \\ \text { Tac 12 } & 15.13 & -92.10 \\ \text { Tac 13 } & 15.12 & -92.11 \\ \text { Tac 14 } & 15.12 & -92.11 \\ \text { Tac 15 } & 15.12 & -92.11 \\ \text { Tac 16 } & 15.12 & -92.11 \\ \text { Tac 17 } & 15.13 & -92.11 \\ \text { Tac 18 } & 15.13 & -92.11\end{array}$

4081
4079
4077
4089
3958
3986
3995
3792
3764
3755
3898
3887
3929

$\begin{array}{ll}2.0 & 0.97541 \\ 2.5 & 0.99977 \\ 2.0 & 0.99687 \\ 2.5 & 0.99858 \\ 1.5 & 0.99129 \\ 1.5 & 0.98564 \\ 1.5 & 0.95418 \\ 1.5 & 0.95905 \\ 1.5 & 0.98316 \\ 1.0 & 0.97223 \\ 1.5 & 0.92531 \\ 1.5 & 0.95965 \\ 3.0 & 0.87414\end{array}$

0.99977

0.99687

99129

0.98564

0.95905

0.98316

0.92531

0.87414

Table 1. Field data and characteristics of rock samples from lava domes, cliff horse-shoe shaped crater and lava from Tacaná volcano, used for the ${ }^{36} \mathrm{Cl} \mathrm{CRE}$ dating calculations. The shielding factor was obtained using the Topographic Shielding Calculator v2.0 provided by CRONUS-Earth Project (2014).

At Instituto de Geofísica (Unidad Morelia; Universidad Nacional Autónoma de México), lichens, mosses and other organic matter were removed from the samples with a brush and then they were crushed with a roller grinder and sieved to retrieve the grain size fraction $(0.25-0.50 \mathrm{~mm})$. Once the crushed samples shipped to the Centre Européen de Recherche et d'Enseignement des Géosciences de l'Environnement (CEREGE; France), aliquots of the bulk rock were first taken for the analysis of the major and trace element concentrations at the "Service d'Analyse des Roches et des Minéraux" (SARM, CRPG, Nancy, France), which are needed to estimate the samples ${ }^{36} \mathrm{Cl}$ production rate from the capture of the lowenergy neutrons by $\mathrm{Cl}$ in the samples (Table 2). This specific ${ }^{36} \mathrm{Cl}$ production reaction is difficult to constrain and associated with significant uncertainties (Schimmelpfennig et al., 2009). As feldspar phenocrysts often contain significantly less $\mathrm{Cl}$ than volcanic whole rock 
samples (Schimmelpfennig et al., 2009), the proportion of the non-magnetic feldspar in the fraction of the sample grains used for ${ }^{36} \mathrm{Cl}$ extraction was increased by discarding the most magnetic minerals with a magnetic separator "Frantz LB-1" at CEREGE. However, because feldspars were not abundant enough, pure feldspar was not used to avoid the risk of too small sample masses with ${ }^{36} \mathrm{Cl}$ contents below the detection limit.

\subsubsection{Chemical sample treatment and measurement}

Between 20 and $100 \mathrm{~g}$ of the feldspar-enriched sample fractions (Tac 1 - Tac 18) were treated for ${ }^{36} \mathrm{Cl}$ extraction following the method described in Schimmelpfennig et al. (2011). The samples were washed in ultrapure water to remove fine-grained powder and then leached in a dilute $\mathrm{HF} / \mathrm{HNO}_{3}$ mixture to dissolve $15-20 \%$ of the initial sample mass. Thus, the samples were decontaminated from atmospheric ${ }^{36} \mathrm{Cl}$ and potentially $\mathrm{Cl}$-rich groundmass grains were reduced (Schimmelpfennig et al., 2009). Then, the samples were dried and $2 \mathrm{~g}$ aliquots of each sample were put aside for analysis of the major elements at SARM, because $\mathrm{Ca}, \mathrm{K}, \mathrm{Ti}$, and $\mathrm{Fe}$ are the target elements for spallogenic/muogenic production of ${ }^{36} \mathrm{Cl}$ (Table 3 ). The following steps consisted in adding a ${ }^{35} \mathrm{Cl}$-enriched spike ( 99\%) to each sample and dissolving totally them in a $\mathrm{HF} / \mathrm{HF} / \mathrm{HNO}_{3}$ mixture. $\mathrm{A}$ chemistry blank was processed following the same protocol as the samples.

After total dissolution, the samples were centrifuged to discard the undissolved residues and gel (fluoride complexes, $\mathrm{CaF}_{2}$ ). Then, chlorine in the liquid solution was precipitated to silver chloride $(\mathrm{AgCl})$ by adding $2 \mathrm{ml}$ of a silver nitrate $\left(\mathrm{AgNO}_{3}\right)$ solution at $10 \%$. To allow the $\mathrm{AgCl}$ to settle down on the bottom of the bottles, samples were stored for 2 days in a dark place. This enabled the extraction of the supernatant solution (excess $\mathrm{HF}$ and $\mathrm{HNO}_{3}$ ) by a peristaltic pump avoiding the disturbance of the $\mathrm{AgCl}$ precipitate. In the next step, aiming to reduce the isobaric interferences of ${ }^{36} \mathrm{~S}$ throughout the ${ }^{36} \mathrm{Cl}$ measurements by Accelerator Mass Spectrometry (AMS), sulphur was removed in the form of barium sulphate $\left(\mathrm{BaSO}_{4}\right)$ obtained after the re-dissolution of this first $\mathrm{AgCl}$ precipitate and the addition of $1 \mathrm{ml}$ of a saturated solution of barium nitrate $\left(\mathrm{Ba}\left(\mathrm{NO}_{3}\right)_{2}\right) \cdot \mathrm{BaSO}_{4}$ was discarded by centrifuging and filtering the supernatant with a syringe and an acrodisc filter. Then, 
$\mathrm{AgCl}$ was precipitated again with 3-4 $\mathrm{ml}$ of diluted $\mathrm{HNO}_{3}(1: 1 \mathrm{vol}$.). The precipitate was collected after centrifuging, was rinsed and finally dried in the oven at $80{ }^{\circ} \mathrm{C}$ for 2 days, and later loaded into nickel cathodes for measurements of the ${ }^{36} \mathrm{Cl} /{ }^{35} \mathrm{Cl}$ and ${ }^{35} \mathrm{Cl} /{ }^{37} \mathrm{Cl}$ ratios by AMS isotope dilution at the French national AMS facility ASTER (CEREGE, France) (Arnold et al., 2013), which took place in 2019 . The ${ }^{36} \mathrm{Cl} /{ }^{35} \mathrm{Cl}$ ratio was normalized to in-

372 house standard SM-CL-12 with an assigned ${ }^{36} \mathrm{Cl} /{ }^{35} \mathrm{Cl}$ ratio of $(1.428 \pm 0.021) \times 10^{-12}$

373 (Merchel et al., 2011), and regarding the ${ }^{35} \mathrm{Cl} /{ }^{37} \mathrm{Cl}$ ratio, a natural ratio of 3.127 was assumed. The AMS analytical data is given in Table 4 .

\subsubsection{In situ-produced ${ }^{36} \mathrm{Cl}$ age calculation}

378 We calculated the ${ }^{36} \mathrm{Cl}$ CRE ages using the Excel spreadsheet published by 379 Schimmelpfennig et al. (2009). We used the following ${ }^{36} \mathrm{Cl}$ production rates and parameters 380 referenced to sea level and high latitude based on the time-invariant "St" scaling (Stone, 381 2000): $42.2 \pm 4.8$ atoms ${ }^{36} \mathrm{Cl}\left(\mathrm{g} \mathrm{Ca}^{-1} \mathrm{yr}^{-1}\right.$ for spallation of $\mathrm{Ca}$ (Schimmelpfennig et al., 382 2011); $148.1 \pm 7.8$ atoms ${ }^{36} \mathrm{Cl}\left(\mathrm{g} \mathrm{K}^{-1} \mathrm{yr}^{-1}\right.$ for spallation of $\mathrm{K}$ (Schimmelpfennig et al., 383 2014); $13 \pm 3$ atoms ${ }^{36} \mathrm{Cl}(\mathrm{g} \mathrm{Ti})^{-1} \mathrm{yr}^{-1}$ for spallation of Ti (Fink et al., 2000); $1.9 \pm 0.2$ atoms $384{ }^{36} \mathrm{Cl}(\mathrm{g} \mathrm{Fe})^{-1} \mathrm{yr}^{-1}$ for spallation of Fe (Stone et al., 2005), and $696 \pm 185$ neutrons (g air) ${ }^{-1} \mathrm{yr}^{-}$ $385^{1}$ at the Earth's surface/atmosphere interface for the production rate of epithermal neutrons 386 from fast neutrons in the atmosphere (Marrero et al., 2016). Both the nucleogenic and 387 muonic scaling factors were determined using the time-invariant scaling model of Stone 388 (2000) based on CosmoCalc (Vermeesch, 2007) and the atmosphere standard model 389 (N.O.A.A., 1976). High-energy neutron attenuation length of $160 \mathrm{~g} \mathrm{~cm}^{-2}$ was used. A 390 density of $2.5 \mathrm{~g} / \mathrm{cm}^{3}$ is assumed for all samples.

392 The topographic shielding factor was estimated applying the Topographic Shielding 393 Calculator v2.0 provided by CRONUS web calculator. The ${ }^{36} \mathrm{Cl} \mathrm{CRE}$ ages are presented 394 without erosion and snow cover corrections. Regarding erosion, all the sampled surfaces 395 are well-preserved whereas potential snow cover effects were not considered because 396 snowfall is very rare in this tropical climate. 


\section{Results}

\subsection{Structural setting and stress regime}

The structural data is presented in figure $4 \mathrm{a}$ and plotted in rose diagrams on figures $4 \mathrm{~b}-\mathrm{c}$. The performed image analyses and field reconnaissance revealed the occurrence of elongated rhombic large scale fractures on top of Las Ardillas dome with a preferential direction between $\mathrm{N} 30^{\circ} \mathrm{E}$ to $\mathrm{N} 70^{\circ} \mathrm{E}$ (Figs. 2 and $4 \mathrm{~b}$ ). These fractures have a NE-SW main axis. Their SW tip ends in a hydrothermal alteration zone with fumaroles on the northern flank of San Antonio volcano and their NE tip is connected with the two NE-SW landslide scars. Along these rhombic fractures occurred the 1949 phreatic explosion, signs of hydrothermal fluid paths, and the two explosion craters described in figures 2 and 4 . The structural analysis of field data in andesitic rocks shows a preferential fracturing system with a $\mathrm{N} 40^{\circ} \mathrm{E}$ to $\mathrm{N} 70^{\circ} \mathrm{E}$ orientation and a secondary one with $\mathrm{NNW}-\mathrm{SSE}$ direction (Fig. 4c). Analysis of all these data allows defining a stress regime atop the TVC represented by a minimum main stress $\left(\sigma_{3}\right)$ with a $\mathrm{N} 40^{\circ} \mathrm{W} \pm 10^{\circ}$ orientation.

\subsection{Cosmogenic ${ }^{36} \mathrm{Cl}$ chronology, lichenometry and dendrochronology.}

In Table 4, the ${ }^{36} \mathrm{Cl} \mathrm{CRE}$ ages are given with their full uncertainties, i.e. including analytical and production rate errors, as well as with their analytical errors only. In the text and figures, individual sample ages are shown with their analytical errors only, while arithmetic mean ages are given with their standard deviations. The age population from each dated volcanic feature was tested for outliers using the $\chi^{2}$ test of Ward and Wilson (1978). The individual ${ }^{36} \mathrm{Cl}$ ages range between $11.0 \pm 1.8 \mathrm{ka}$ and $170 \pm 70$ years. Most of the sample fractions that were little enriched in feldspar (see section 3.5.1), have high natural $\mathrm{Cl}$ concentrations (up to $\sim 265 \mathrm{ppm}$ ), while $\mathrm{Cl}$ concentrations as low as $13 \mathrm{ppm}$ were obtained in sample fractions with a high feldspar proportion. This led to $\sim 10-65 \%$ 
429 contributions from Cl-derived ${ }^{36} \mathrm{Cl}$ to the total ${ }^{36} \mathrm{Cl}$ production and associated uncertainties

430 in resulting ages of up to $\sim 22 \%$ (Table 2 and 3 ).

\subsubsection{Tacaná summit domes}

434 The summit "East", "Northwest" and "Southwest" lava domes are hosted within the $600 \mathrm{~m}$ 435 wide horseshoe-shaped crater of Tacaná that is breached to the northwest (Figs. 2 and 3). 436 They have a bulby shape, with three recognizable lobes. Together these domes occupy an 437 area of $0.18 \mathrm{~km}^{2}$, with a radius of approximate $300 \mathrm{~m}$, and correspond to a volume of 0.017 $438 \mathrm{~km}^{3}$. The highest dome ("East dome") has an elevation of $4060 \mathrm{~m}$ a.s.l. It rises $87 \mathrm{~m}$ above 439 the surrounding terrain and holds an older microwave antenna. This dome is separated from 440 the "Northwest" and "Southwest" domes by a N-S fault scar. The western lava lobes reach

441 a maximum elevation of $3990 \mathrm{~m}$ and they are not easily distinguished from the Eastern 442 dome.

444 The summit of the "Northwest" and "Southwest" domes are separated by a 15 m depression 445 in north-south direction. The "Southwest" dome emplaced an olivine-bearing lava to the 446 southwest, and both are affected by the large NE-SW scar open to the southwest. The 447 "Southwest" and the "Northwest" domes have an andesitic composition of 62.48 wt.\% $\mathrm{SiO}_{2}$ 448 and 62.65 wt.\% $\mathrm{SiO}_{2}$, respectively. A dacitic composition with 63.6 wt.\% $\mathrm{SiO}_{2}$ (on 449 anhydrous basis) has been evidenced on the "East" dome (Fig. 5a). The olivine-bearing 450 lava is the most mafic lava analyzed. It is andesitic in composition (Fig. 5a) with 57.5 wt.\% $451 \quad \mathrm{SiO}_{2}$ that falls close to the basaltic andesitic field.

452

Samples

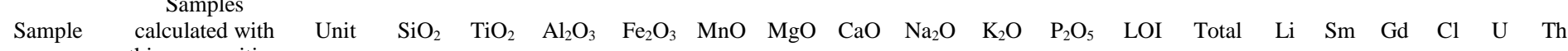
this composition

\begin{tabular}{|c|c|c|c|c|c|c|c|c|c|c|c|c|c|c|c|c|c|c|c|c|}
\hline *Tac0911 & - & PreCL & 60.27 & 0.64 & 17.11 & 6.48 & 0.11 & 2.36 & 5.98 & 3.78 & 2.23 & 0.17 & 0.27 & 99.40 & - & & - & - & - & 3 \\
\hline *Tac0808 & - & AndL & 59.51 & 0.66 & 18.03 & 6.54 & 0.12 & 2.67 & 6.23 & 3.64 & 2.08 & 0.19 & 0.23 & 99.90 & - & & - & - & & 4 \\
\hline *Tac0829E & - & $\mathrm{ME}$ & 53.69 & 0.95 & 18.56 & 8.53 & 0.12 & 4.06 & 8.36 & 3.58 & 1.23 & 0.20 & 0.21 & 99.49 & - & & - & - & & 3 \\
\hline *Tac0829L & - & AndL & 61.13 & 0.57 & 16.83 & 5.73 & 0.10 & 2.42 & 5.62 & 3.71 & 2.23 & 0.15 & 1.38 & 99.87 & - & 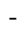 & - & - & - & 4 \\
\hline *Tac0829a & - & AndL & 62.27 & 0.59 & 16.83 & 5.60 & 0.10 & 2.21 & 5.40 & 3.80 & 2.32 & 0.16 & 0.35 & 99.63 & - & - & - & - & - & 4 \\
\hline
\end{tabular}




\begin{tabular}{|c|c|c|c|c|c|c|c|c|c|}
\hline Sample & $\mathrm{CaO}(\%)$ & $\mathrm{K}_{2} \mathrm{O}(\%)$ & $\mathrm{TiO}_{2}(\%)$ & $\mathrm{Fe}_{2} \mathrm{O}_{3}(\%)$ & $\begin{array}{c}\mathrm{SiO}_{2} \\
(\%)\end{array}$ & $\begin{array}{c}\mathrm{Na}_{2} \mathrm{O} \\
(\%)\end{array}$ & $\begin{array}{c}\mathrm{MgO} \\
(\%)\end{array}$ & $\begin{array}{c}\mathrm{Al}_{2} \mathrm{O}_{3} \\
(\%)\end{array}$ & $\begin{array}{c}\mathrm{MnO} \\
(\%)\end{array}$ \\
\hline
\end{tabular}

\begin{tabular}{|c|c|c|c|c|c|c|c|c|c|c|c|c|c|c|c|c|c|c|c|c|}
\hline$*$ Tac0827 & - & PreCL & 58.70 & 0.61 & 16.67 & 6.15 & 0.11 & 2.52 & 5.70 & 3.62 & 2.13 & 0.16 & 3.23 & 99.60 & - & - & - & - & - & 4 \\
\hline *Tac0823 & - & $\begin{array}{c}\text { And- } \\
\text { Ol }\end{array}$ & 57.28 & 0.80 & 17.74 & 7.25 & 0.11 & 3.88 & 7.21 & 3.59 & 1.68 & 0.17 & 0.08 & 99.79 & - & - & - & - & - & 3 \\
\hline *Tac0809 & - & Dome & 60.77 & 0.64 & 17.38 & 6.23 & 0.11 & 2.63 & 5.96 & 3.69 & 2.15 & 0.17 & 0.23 & 99.96 & - & - & - & - & - & 3 \\
\hline *Tac0811 & - & Dome & 62.61 & 0.56 & 16.69 & 5.57 & 0.10 & 2.30 & 5.41 & 3.69 & 2.38 & 0.16 & 0.24 & 99.71 & - & - & - & - & - & 3 \\
\hline **Tac9878 & - & Dome & 62.78 & 0.55 & 16.88 & 5.26 & 0.10 & 2.17 & 5.34 & 3.70 & 2.32 & 0.15 & 0.80 & 100.05 & - & - & - & - & - & - \\
\hline ***Tac9863 & - & ArD & 62.96 & 0.58 & 16.76 & 4.82 & 0.11 & 2.42 & 5.74 & 3.82 & 2.06 & 0.13 & 0.60 & 100.00 & - & 4.2 & - & - & 2.8 & 4.7 \\
\hline${ }^{1}$ TAC-1 & Tac 2, 3 & Dome & 61.25 & 0.62 & 16.22 & 6.05 & 0.11 & 2.46 & 5.22 & 3.65 & 2.31 & 0.15 & 1.12 & 99.16 & 24 & 3.3 & 2.8 & 300 & 1.4 & 4.35 \\
\hline${ }^{1}$ TAC-4 & Tac 5, 6 & Dome & 61.98 & 0.62 & 15.50 & 6.08 & 0.11 & 2.52 & 4.72 & 3.52 & 2.27 & 0.13 & 1.96 & 99.40 & 24 & 3.2 & 2.7 & 280 & 1.4 & 4.28 \\
\hline${ }^{1}$ TAC-7 & Tac 8,9 & Dome & 61.42 & 0.61 & 16.16 & 5.75 & 0.11 & 2.59 & 5.28 & 3.62 & 2.34 & 0.14 & 1.34 & 99.36 & 25 & 3.1 & 2.7 & 370 & 1.5 & 4.23 \\
\hline${ }^{1}$ TAC-10 & Tac 11,12 & PreCL & 61.16 & 0.64 & 16.19 & 6.80 & 0.13 & 2.41 & 5.07 & 3.59 & 2.38 & 0.17 & 0.65 & 99.19 & 21 & 3.1 & 2.7 & 72 & 1.5 & 4.16 \\
\hline${ }^{1}$ TAC-13 & Tac 14,15 & $\operatorname{ArD}$ & 64.53 & 0.53 & 15.75 & 5.07 & 0.10 & 2.07 & 4.52 & 3.74 & 2.72 & 0.14 & 0.44 & 99.61 & 25 & 2.9 & 2.5 & 335 & 1.7 & 5.01 \\
\hline${ }^{1}$ TAC-16 & Tac 17,18 & AndL & 64.36 & 0.51 & 15.83 & 4.72 & 0.09 & 1.87 & 4.55 & 3.73 & 2.65 & 0.14 & 0.72 & 99.16 & 24 & 2.8 & 2.4 & 320 & 1.7 & 5 \\
\hline
\end{tabular}

453 Table 2. Major and trace element concentrations in bulk rock samples from Tacaná Volcanic 454 Complex, before chemical treatment (see methods). We used the composition of one sample per 455 landform for the age calculations of all other samples from the same feature, assuming that 456 variations in compositions are insignificant. LOI, loss on ignition; total $\mathrm{Fe}$ as $\mathrm{Fe}_{2} \mathrm{O}_{3}$. Compiled 457 samples from Tacaná summit: *Limón-Hernández (2009). Units are: PreCL, Pre-colapse lava; 458 AndL, Andesitic lava; ME, Mafic enclave; And-Ol, olivine-bearing andesitic lava; ArD, Ardillas 459 dome. References: **Mora et al. (2004); ***García-Palomo et al. (2006); ${ }^{1}$ This work. 


\begin{tabular}{|c|c|c|c|c|c|c|c|c|c|}
\hline \multicolumn{10}{|c|}{$\begin{array}{l}\text { Eastern lava } \\
\text { dome }\end{array}$} \\
\hline Tac 1 & $6.08 \pm 0.30$ & $1.94 \pm 0.10$ & $0.32 \pm 0.08$ & $3.07 \pm 0.46$ & 62.71 & 4.04 & 2.12 & 18.09 & 0.08 \\
\hline Tac 2 & $5.52 \pm 0.28$ & $1.78 \pm 0.17$ & $0.26 \pm 0.05$ & $2.54 \pm 0.38$ & 65.35 & 3.66 & 1.68 & 16.60 & 0.07 \\
\hline Tac 3 & $6.21 \pm 0.31$ & $1.90 \pm 0.40$ & $0.31 \pm 0.07$ & $2.98 \pm 0.45$ & 62.49 & 4.09 & 2.10 & 18.38 & 0.08 \\
\hline \multicolumn{10}{|c|}{$\begin{array}{l}\text { Northwestern } \\
\text { lava dome }\end{array}$} \\
\hline Tac 4 & $8.33 \pm 0.42$ & $0.60 \pm 0.12$ & $0.06 \pm 0.02$ & $0.65 \pm 0.09$ & 60.40 & 4.59 & 0.21 & 22.66 & 0.02 \\
\hline Tac 5 & $6.38 \pm 0.32$ & $1.43 \pm 0.28$ & $0.22 \pm 0.05$ & $2.05 \pm 0.31$ & 63.36 & 3.89 & 1.43 & 18.31 & 0.06 \\
\hline Tac 6 & $6.75 \pm 0.33$ & $1.32 \pm 0.13$ & $0.21 \pm 0.05$ & $2.18 \pm 0.33$ & 61.63 & 4.11 & 1.41 & 19.58 & 0.06 \\
\hline \multicolumn{10}{|c|}{$\begin{array}{c}\text { Southwestern } \\
\text { lava dome }\end{array}$} \\
\hline Tac 7 & $9.14 \pm 0.46$ & $0.60 \pm 0.15$ & $0.05 \pm 0.01$ & $0.58 \pm 0.09$ & 57.21 & 5.25 & 0.18 & 25.29 & 0.02 \\
\hline Tac 8 & $6.41 \pm 0.32$ & $1.82 \pm 0.36$ & $0.29 \pm 0.07$ & $2.53 \pm 0.38$ & 62.07 & 4.18 & 1.76 & 18.69 & 0.07 \\
\hline Tac 9 & $6.78 \pm 0.34$ & $1.66 \pm 0.33$ & $0.25 \pm 0.06$ & $2.20 \pm 0.33$ & 61.66 & 4.38 & 1.62 & 19.77 & 0.06 \\
\hline \multicolumn{10}{|c|}{$\begin{array}{l}\text { Cliff horse-shoe } \\
\text { shaped crater }\end{array}$} \\
\hline Tac 10 & $6.76 \pm 0.34$ & $1.47 \pm 0.29$ & $0.24 \pm 0.05$ & $2.73 \pm 0.41$ & 61.68 & 4.21 & 1.27 & 19.86 & 0.07 \\
\hline Tac 11 & $9.52 \pm 0.48$ & $0.45 \pm 0.09$ & $0.04 \pm 0.01$ & $0.54 \pm 0.08$ & 57.43 & 5.15 & 0.08 & 25.73 & 0.02 \\
\hline Tac 12 & $6.82 \pm 0.34$ & $1.33 \pm 0.26$ & $0.19 \pm 0.05$ & $2.64 \pm 0.40$ & 62.23 & 4.11 & 1.77 & 19.63 & 0.08 \\
\hline \multicolumn{10}{|c|}{$\begin{array}{l}\text { Ardillas lava } \\
\text { dome }\end{array}$} \\
\hline Tac 13 & $7.44 \pm 0.37$ & $1.37 \pm 0.18$ & $0.23 \pm 0.06$ & $2.16 \pm 0.22$ & 60.37 & 4.50 & 1.54 & 21.05 & 0.06 \\
\hline Tac 15 & $6.71 \pm 0.33$ & $1.69 \pm 0.17$ & $0.26 \pm 0.06$ & $2.47 \pm 0.25$ & 61.95 & 4.33 & 1.79 & 19.79 & 0.07 \\
\hline \multicolumn{10}{|c|}{$\begin{array}{l}\text { Andesitic } \\
\text { lava }\end{array}$} \\
\hline Tac 16 & $7.43 \pm 0.37$ & $1.32 \pm 0.13$ & $0.24 \pm 0.06$ & $2.14 \pm 0.21$ & 60.52 & 4.51 & 1.50 & 21.06 & 0.06 \\
\hline Tac 17 & $7.32 \pm 0.37$ & $1.35 \pm 0.13$ & $0.34 \pm 0.08$ & $3.29 \pm 0.33$ & 59.43 & 4.24 & 2.47 & 19.64 & 0.09 \\
\hline Tac 18 & $7.46 \pm 0.37$ & $1.28 \pm 0.13$ & $0.20 \pm 0.05$ & $1.94 \pm 0.19$ & 59.97 & 4.55 & 1.32 & 21.21 & 0.05 \\
\hline
\end{tabular}

460 Table 3. Concentrations of the major elements, including the ${ }^{36} \mathrm{Cl}$ target elements $\mathrm{Ca}, \mathrm{K}$, Ti and $\mathrm{Fe}$, 461 measured in splits taken from the samples after magnetic separation and the chemical pre-treatment. 462 Analyses carried out at Service d'Analyse des Roches et des Minéraux (SARM, CRPG, Nancy, 463 France) by ICP-OES. 


\begin{tabular}{|c|c|c|c|c|c|c|c|}
\hline Sample & $\begin{array}{c}\text { Sample } \\
\text { weight } \\
\text { (g) }\end{array}$ & $\begin{array}{c}\text { Mass } \mathrm{Cl}(\mathrm{mg}) \text { added by } \\
\text { spike }\end{array}$ & ${ }^{35} \mathrm{Cl} /{ }^{37} \mathrm{Cl}$ & ${ }^{36} \mathrm{Cl} /{ }^{35} \mathrm{Cl}\left(10^{14}\right)$ & $\mathrm{Cl}(\mathrm{ppm})$ & ${ }^{36} \mathrm{Cl}$ conc $\left(10^{3}\right.$ at $\mathrm{g}^{-}$ & ${ }^{36} \mathrm{Cl}$ age (ka) \\
\hline \multicolumn{8}{|c|}{$\begin{array}{l}\text { Eastern lava } \\
\text { dome }\end{array}$} \\
\hline Tac 1 & 66.87 & 2.016 & $3.595 \pm 0.043$ & $26.9 \pm 1.4$ & $265 \pm 38$ & $1060 \pm 150$ & $9.7 \pm 2.1(1.4)$ \\
\hline Tac 2 & 76.12 & 2.009 & $3.712 \pm 0.045$ & $21.9 \pm 1.3$ & $185 \pm 25$ & $621 \pm 80$ & $7.3 \pm 1.5(1.0)$ \\
\hline Tac 3 & 79.13 & 2.013 & $3.524 \pm 0.042$ & $31.5 \pm 1.7$ & $263 \pm 40$ & $1210 \pm 180$ & $11.0 \pm 2.5(1.8)$ \\
\hline \multicolumn{8}{|c|}{$\begin{array}{l}\text { Northwestern } \\
\text { lava dome }\end{array}$} \\
\hline Tac 4 & 25.77 & 2.010 & $8.53 \pm 0.10$ & $21.6 \pm 1.3$ & $57 \pm 7$ & $449 \pm 32$ & $9.7 \pm 1.4(1.0)$ \\
\hline Tac 5 & 59.54 & 2.012 & $3.841 \pm 0.046$ & $22.4 \pm 1.2$ & $194 \pm 25$ & $690 \pm 82$ & $8.0 \pm 1.6(1.1)$ \\
\hline Tac 6 & 40.6 & 2.018 & $4.574 \pm 0.054$ & $23.4 \pm 1.3$ & $140 \pm 17$ & $622 \pm 61$ & $8.9 \pm 1.6(1.0)$ \\
\hline \multicolumn{8}{|c|}{$\begin{array}{l}\text { Southwestern } \\
\text { lava dome }\end{array}$} \\
\hline Tac 7 & 19.7 & 2.019 & $8.66 \pm 0.53$ & $18.8 \pm 2.0$ & $73 \pm 11$ & $507 \pm 60$ & $9.8 \pm 1.7$ \\
\hline Tac 8 & 82.81 & 2.003 & $3.625 \pm 0.043$ & $20.6 \pm 1.2$ & $200 \pm 28$ & $615 \pm 84$ & $6.7 \pm 1.4(1.0)$ \\
\hline Tac 9 & 60.73 & 2.013 & $3.736 \pm 0.044$ & $27.0 \pm 1.4$ & $224 \pm 30$ & $931 \pm 115$ & $9.4 \pm 2.0(1.3)$ \\
\hline \multicolumn{8}{|c|}{$\begin{array}{l}\text { Cliff horse-shoe } \\
\text { shaped crater }\end{array}$} \\
\hline Tac 10 & 55.27 & 2.019 & $9.62 \pm 0.11$ & $22.4 \pm 1.3$ & $22 \pm 3$ & $205 \pm 14$ & $5.29 \pm 0.72(0.64)$ \\
\hline Tac 11 & 14.68 & 2.015 & $34.75 \pm 0.43$ & $1.08 \pm 0.20$ & $13 \pm 2$ & $22.2 \pm 6.5$ & $0.66 \pm 0.21(0.20)$ \\
\hline Tac 12 & 58.8 & 2.009 & $7.109 \pm 0.084$ & $26.8 \pm 1.4$ & $34 \pm 4$ & $276 \pm 20$ & $6.99 \pm 0.95(0.81)$ \\
\hline \multicolumn{8}{|c|}{$\begin{array}{c}\text { Ardillas lava } \\
\text { dome }\end{array}$} \\
\hline Tac 13 & 69.06 & 2.056 & $3.789 \pm 0.045$ & $0.88 \pm 0.20$ & $185 \pm 24$ & $24.2 \pm 6.3$ & $\begin{array}{c}0.339 \pm 0.102 \\
(0.099)\end{array}$ \\
\hline Tac 14 & 30.79 & 2.008 & $10.60 \pm 0.13$ & $0.140 \pm 0.063$ & $33 \pm 4$ & - & - \\
\hline Tac 15 & 63.5 & 2.022 & $3.866 \pm 0.046$ & $0.46 \pm 0.15$ & $177 \pm 23$ & $11.8 \pm 4.4$ & $\begin{array}{c}0.169 \pm 0.069 \\
(0.065)\end{array}$ \\
\hline \multicolumn{8}{|c|}{ Andesitic lava } \\
\hline Tac 16 & 50.98 & 2.043 & $4.078 \pm 0.048$ & $1.18 \pm 0.24$ & $172 \pm 22$ & $32.9 \pm 7.8$ & $0.47 \pm 0.13(0.11)$ \\
\hline Tac 17 & 53.27 & 2.040 & $4.039 \pm 0.048$ & $0.79 \pm 0.19$ & $172 \pm 22$ & $21.2 \pm 6.0$ & $\begin{array}{c}0.294 \pm 0.092 \\
(0.085)\end{array}$ \\
\hline Tac 18 & 61.72 & 2.027 & $3.931 \pm 0.047$ & $1.15 \pm 0.23$ & $167 \pm 21$ & $30.0 \pm 7.1$ & $0.44 \pm 0.13(0.11)$ \\
\hline Blank 01 & - & 2.002 & $116.4 \pm 1.5$ & $0.23 \pm 0.16$ & - & - & - \\
\hline
\end{tabular}

469

470 Table 4. Analytical ${ }^{36} \mathrm{Cl}$ data and resulting ${ }^{36} \mathrm{Cl} \mathrm{CRE}$ ages for samples from Tacaná Volcanic 471 Complex. Age uncertainties $(1 \sigma)$ include production rate errors as well as analytical errors; numbers 472 in parenthesis correspond to analytical errors only.

473

474 
476 Figure 6 and Table 4 (also supplement material) present the nine ${ }^{36} \mathrm{Cl} \mathrm{CRE}$ ages calculated 477 from the samples collected at the summit lava domes "East", "Northwest" and "Southwest" 478 of Tacaná volcano. On the "East" dome, samples Tac-1, -2 and -3 lead to ${ }^{36} \mathrm{Cl} \mathrm{CRE}$ ages of $4799.7 \pm 1.4 \mathrm{ka}, 7.3 \pm 1.0 \mathrm{ka}, 11.0 \pm 1.8 \mathrm{ka}$, respectively. Considering their associated 480 uncertainties, they are statistically indistinguishable and lead to an arithmetic mean ${ }^{36} \mathrm{Cl}$ 481 CRE age and standard deviation of $9.3 \pm 1.9 \mathrm{ka}$. On the "Northwest" dome, the calculated

$482{ }^{36} \mathrm{Cl}$ CRE ages of $9.7 \pm 1.0 \mathrm{ka}, 8.0 \pm 1.1 \mathrm{ka}$ and $8.9 \pm 1.0$ (samples Tac-4, -5 and -6 ) lead to 483 an arithmetic mean ${ }^{36} \mathrm{Cl} \mathrm{CRE}$ age of $8.9 \pm 0.9 \mathrm{ka}$, whereas on the "Southwest" dome, the 484 calculated ${ }^{36} \mathrm{Cl} \mathrm{CRE}$ ages of $9.8 \pm 1.3 \mathrm{ka}, 6.7 \pm 1.0 \mathrm{ka}$ and $9.4 \pm 1.3 \mathrm{ka}$ (samples Tac-7, -8 , 485 and -9) lead to an arithmetic mean ${ }^{36} \mathrm{Cl} \mathrm{CRE}$ age of $8.6 \pm 1.7 \mathrm{ka}$. Dendrochronological data 486 around the summit area lead to tree ages ranging from 83 to 164 years. The youngest trees 487 are located on the summit of Tacaná dome (83 years, A1, Juniperus monticola) at $4058 \mathrm{~m}$ 488 a. s. 1. A similar age (<100 years) from the thali of Rhizocarpon geographicum is obtained.

\subsubsection{Horseshoe-shaped crater of Tacaná volcano}

Remnant lavas from the horseshoe-shaped crater of Tacaná are distributed to the south, east and southeast of the main Tacaná edifice (Figs. 2 and 6). As mentioned before, the $600 \mathrm{~m}$ wide crater breached to the NW was produced by the $15 \pm 5$ ka collapse. Samples from these lavas, which were analyzed in this work, have an andesitic composition (60 wt.\% $\mathrm{SiO}_{2}$ ) with 6 wt.\% alkalies (Fig. 5a). Furthermore, the three samples for ${ }^{36} \mathrm{Cl} \mathrm{CRE}$ dating from the southern edge of the horseshoe-shaped crater (samples Tac-10, -11 and -12) lead to ${ }^{36} \mathrm{Cl} \mathrm{CRE}$ ages of $5.3 \pm 0.6 \mathrm{ka}, 0.7 \pm 0.2 \mathrm{ka}$ and $7.0 \pm 0.8 \mathrm{ka}$, respectively (Fig. 6, Table 4 498 and supplement material).

\subsection{3. "Andesitic lava"}

502 The "Andesitic lava" was vented at the base of the "Southwest" dome of Tacaná and at the 503 large NE-SW horseshoe-shaped crater (Figs. 2 and 6). Three samples from these lavas that 504 hosted basaltic andesite mafic enclaves were collected. The geochemical analysis of pure 505 lava samples have an andesitic composition varying from 59 to 62 wt. $\% \mathrm{SiO}_{2}$, although one sample lies at the limit between andesite and dacite compositions (63 wt.\% $\mathrm{SiO}_{2}$, on 
anhydrous basis) (Fig. 5a; Table 2). The lava composition is similar to that from the

508 "Southwest" dome and periphery lavas (Fig. 5b-g) and the sampled mafic enclaves are

509 similar to other enclaves reported in previous works (Mora et al., 2004; 2013). Besides, the

510 three ${ }^{36} \mathrm{Cl} \mathrm{CRE}$ ages from these "Andesitic" lava samples Tac 16, 17, 18 are $0.5 \pm 0.1 \mathrm{ka}$,

$5110.3 \pm 0.1 \mathrm{ka}$ and $0.4 \pm 0.1 \mathrm{ka}$, respectively (Fig 6, Table 4 and supplement material).

512 Considering their associated uncertainties, they are statistically indistinguishable and lead

513 to a mean ${ }^{36} \mathrm{Cl} \mathrm{CRE}$ age of $0.4 \pm 0.1 \mathrm{ka}$. Furthermore, lichenometry lead to a minimum age

514 of 390 years (Fig. 7).

515

516

517 The chemical analyses of two samples from the Ardillas dome (Table 2) complemented 518 with one sample from a previous work (García-Palomo et al., 2006) indicate that the 519 Ardillas dome is the most silicic structure of the TVC. It is dacitic in composition (Fig. 5a) 520 with silica contents of 63-65 wt.\% and alkalies of 5.8-6.5 wt.\%. All the samples have the 521 lowest values in $\mathrm{MgO}, \mathrm{CaO}, \mathrm{Fe}_{2} \mathrm{O}_{3}$, and $\mathrm{Al}_{2} \mathrm{O}_{3}$ (Fig. 5b-g), according to their more evolved 522 character (more silica rich). Figure 6 and Table 4 (also supplement material) present the

$523{ }^{36} \mathrm{Cl}$ CRE ages of the Ardillas lava dome, which are $0.3 \pm 0.1 \mathrm{ka}$ and $0.2 \pm 0.1 \mathrm{ka}$ (Tac-13 524 and -15) and lead to a mean ${ }^{36} \mathrm{Cl} \mathrm{CRE}$ age of $0.3 \pm 0.1 \mathrm{ka}$. Due to the number of ${ }^{36} \mathrm{Cl}$ atoms 525 determined by AMS for sample Tac 14 being similar to that determined for the chemically 526 processed blank considering their associated analytical uncertainties, it is not possible to 527 calculate an exposure age for this sample. However, its ${ }^{36} \mathrm{Cl}$ concentration close to the 528 chemical blank value indicates a very short exposure duration. On top of the Ardillas dome, 529 the tree ages range from 117 to 164 years, whereas trees closer to the eastern vertical wall 530 of the dome have ages ranging from 117 to 138 years (supplement material). In addition, 531 lichenometry provides a minimum age of 300 years (Fig. 7). 

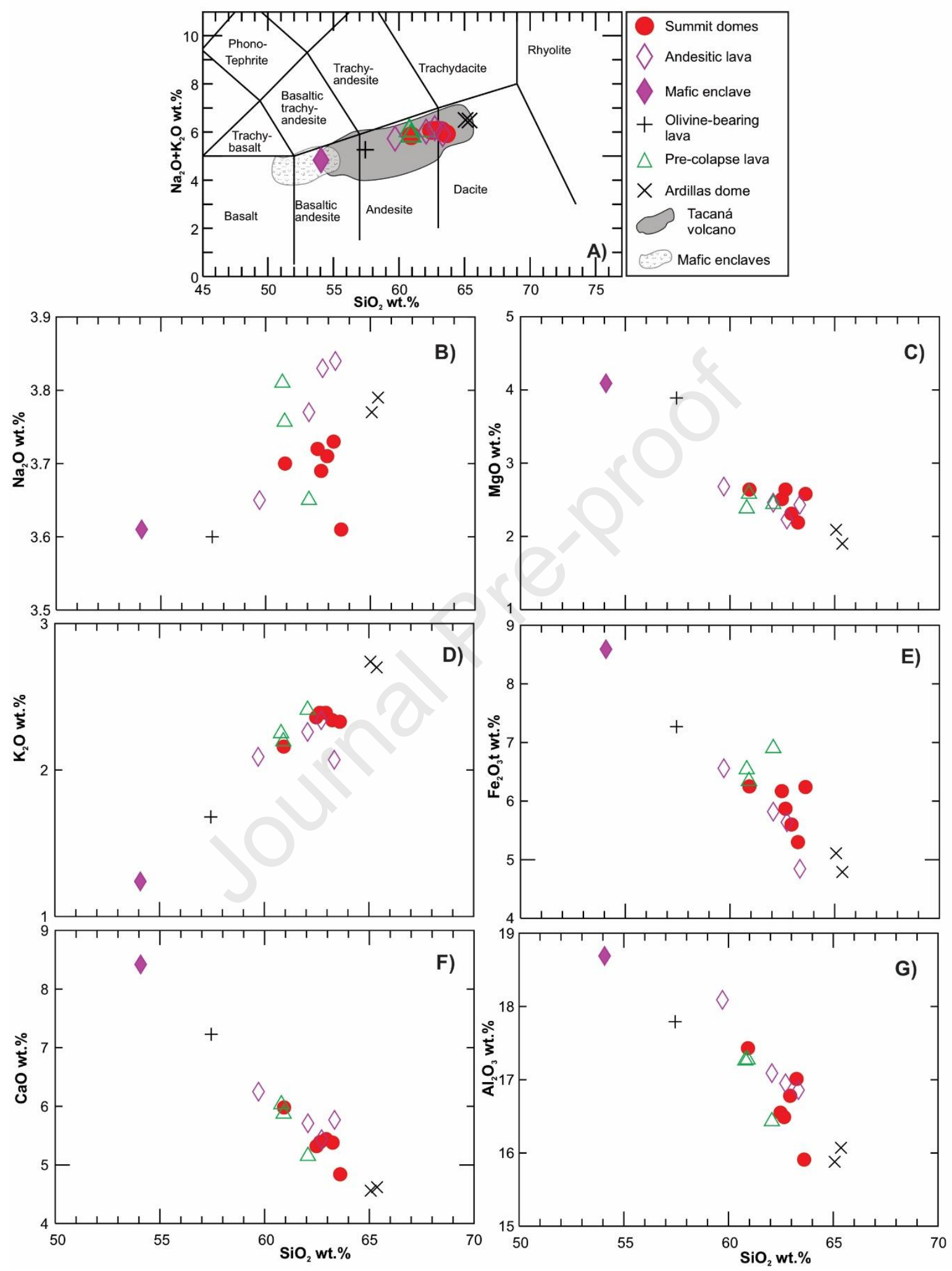

Figure 5. Whole-rock chemical composition of Tacaná samples. A) Total alkalies vs silica diagram (Le Bas et al., 1986) and B-G) binary diagrams. All samples were plotted on anhydrous basis. Gray and dotted areas were taken from previous works (Mora et al., 2004; Arce et al., 2015). 


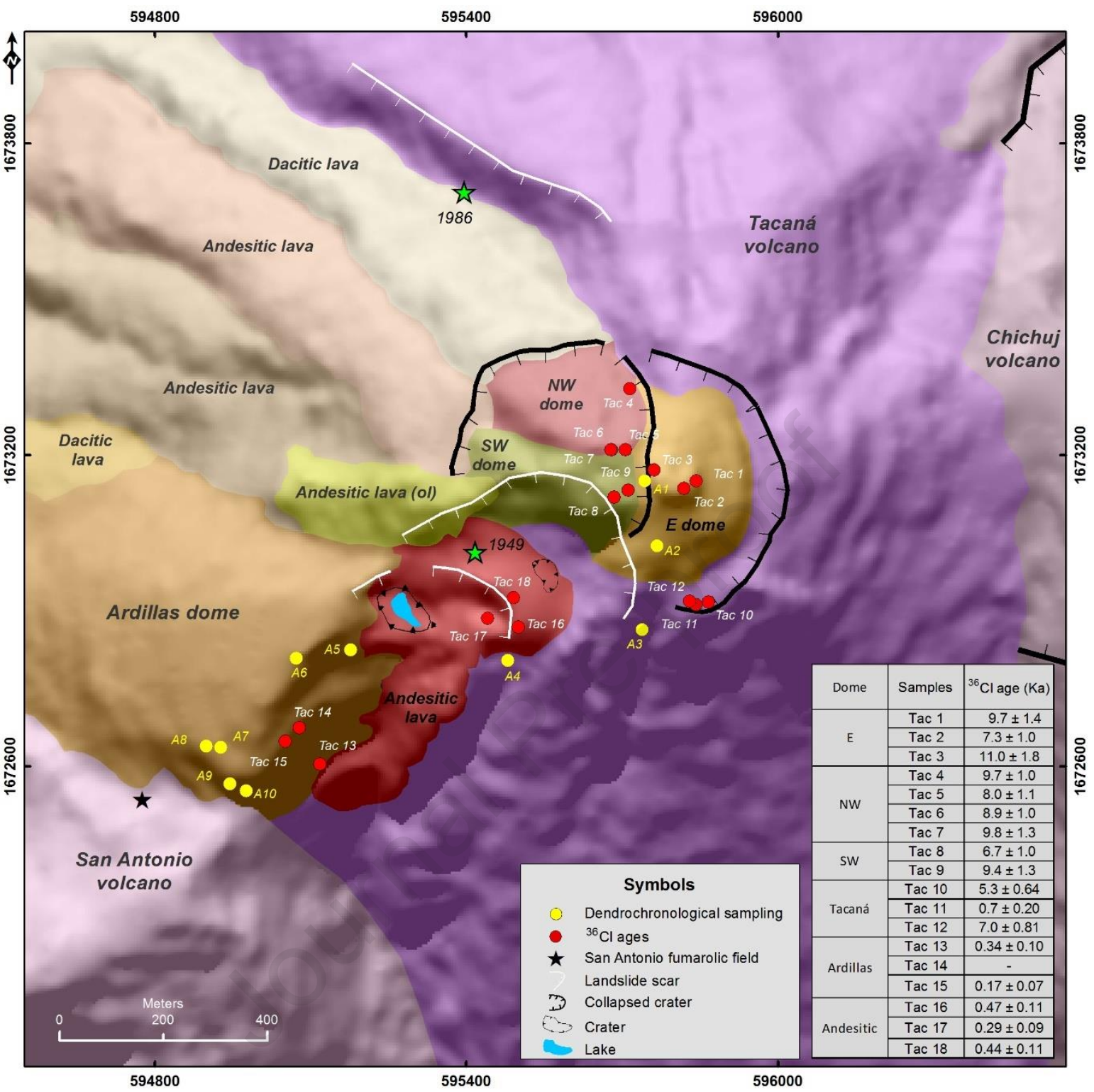

Figure 6. Geological map of Tacaná Volcanic Complex. The red spots indicate the location of the samples collected for ${ }^{36} \mathrm{Cl} \mathrm{CRE}$ dating. 


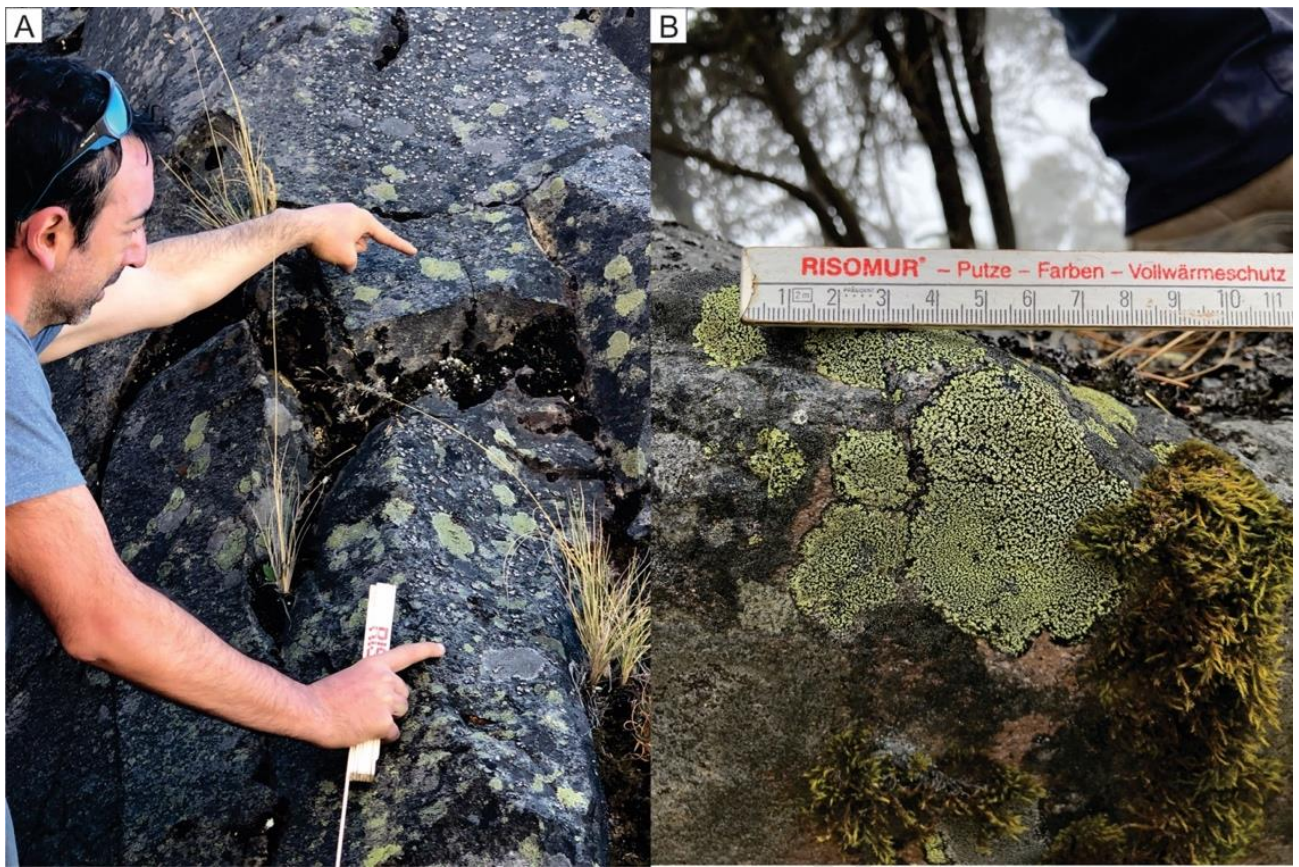

Figure 7. Detailed photographs of Rhizocarpon geographicum. A) A colony formed by several individuals whom oldest specimen is 390 years, growing on the surface of the "Andesitic lava"; B) The biggest specimen of Rhizocarpon geographicum found at the Ardillas dome yield a minimum age of 300 years.

\section{Discussion}

\subsection{Interpretation of the ${ }^{36} \mathrm{Cl} \mathrm{CRE}$, lichenometry and dendrochronological ages}

In this study, ${ }^{36} \mathrm{Cl} \mathrm{CRE} \mathrm{dating} \mathrm{was} \mathrm{used} \mathrm{to} \mathrm{determine} \mathrm{the} \mathrm{age} \mathrm{of} \mathrm{four} \mathrm{lava} \mathrm{domes,} \mathrm{one}$ horseshoe-shaped crater and one lava from the summit and the upper part of TVC. Based on the geomorphology and field observations, the oldest rocks of the TVC summit seem to be the lavas cut by the collapse scar, followed by lavas that filled the horseshoe-shaped crater ending with extrusion of the summit domes (Figs. 2 and 6). The ${ }^{36} \mathrm{Cl} \mathrm{CRE} \mathrm{ages}$ obtained from the three summit lava domes are statistically indistinguishable considering their associated uncertainties and provide evidence of an important effusive episode at around $9 \mathrm{ka}$. These ages are in good agreement with the explosive Once de Abril eruption that occurred ca.10 ka $\left({ }^{14} \mathrm{C}\right.$ age $)$ and dispersed a succession of dense and dilute PDCs (Macías et al., 2015). Also at ca. 10 ka (Limón-Hernández, 2011), another debris avalanche, called Tuimanj, occurred towards the north associated with a smaller collapse on the northern part of the Tacaná scar crater (at Tuimanj hamlet). Hence, Once de Abril 
eruption and Tuimanj debris avalanche were followed by a voluminous effusive cycle that emplaced the three summit lava domes.

572 Based on the morphology and erosion of the Tacaná summit, it can be deduced that the first 573 dome extruded inside the horseshoe-shaped crater was the "East" dome (radio anthenna) at $5749.3 \pm 1.9 \mathrm{ka}$. It is quite likely that during its growing stage, parts of the dome collapse to the 575 west producing a N-S scar. This is a common feature in growing domes in which unstable 576 parts fail due to the action of the gravity (e.g. Colima volcano, Saucedo et al., 2004). 577 Afterwards, a new batch of andesitic magma emplaced to the west of this N-S scar erecting 578 first the "Northwest" $(8.9 \pm 0.9 \mathrm{ka})$ and shortly after the "Southwest" $(8.6 \pm 1.7 \mathrm{ka})$ 579 andesitic domes. The tree ages around the summit area range from 83 to 164 years, being in 580 good agreement with that of $<100$ years inferred from the thali of Rhizocarpon 581 geographicum. Obviously, these two ages are not related to the emplacement of the summit 582 domes ("East", "Northwest", and "Southwest"), but indicate growth recovery after the 1902 583 eruption of Santa Maria volcano that covered the summit of Tacaná with at least $15 \mathrm{~cm}$ of 584 ash. This eruption produced a tree-ring growth suppression event in the Pinus hartwegii 585 recorded from 1903 to 1908 (Carlón et al., 2020). Therefore, the ${ }^{36} \mathrm{Cl} \mathrm{CRE}$ results document 586 that intense effusive activity filled the summit of Tacaná during the Early Holocene.

587 By contrast, the ${ }^{36} \mathrm{Cl} \mathrm{CRE}$ ages of ca. 5-7 ka for the lava forming the southern edge of the 588 horseshoe-shaped crater are around $9 \mathrm{ka}$ younger than the associated debris avalanche 589 deposit according to its ${ }^{40} \mathrm{Ar} /{ }^{39} \mathrm{Ar}$ age of $15 \pm 5 \mathrm{ka}$ (Macías et al., 2010). Further, they are 590 not consistent with the ${ }^{36} \mathrm{Cl} \mathrm{CRE}$ ages of the summit domes (ca. $9 \mathrm{ka}$ ), which are 591 stratigraphically younger than the horseshoe-shaped crater and chemically 592 undistinguishable from the samples of the domes (Fig. 5b-g). We therefore infer an 593 underestimation of the ${ }^{36} \mathrm{Cl} \mathrm{CRE}$ ages of the horseshoe-shaped crater and hypothesize that 594 gravitational processes affected the limit of the steep cliff of the horseshoe-shaped crater 595 from where the samples were collected. This implies that the sampled surfaces were 596 exposed several thousand years after the collapse event. Therefore, we assume that the ${ }^{36} \mathrm{Cl}$ 597 CRE ages should be considered as minimum ages of the volcanic collapse. 
598 As the Ardillas lava dome is older than $760 \pm 30 \mathrm{yr}$ BP (Macías et al., 2018), we suspect

599 that the ${ }^{36} \mathrm{Cl} \mathrm{CRE}$ dates $(0.3 \pm 0.1 \mathrm{ka})$ underestimate the age of the emplacement of this

600 dome. The sampled sites at this structure were to the right of the tensional fractures and

601 very close to an unstable vertical cliff (Fig. 2 and supplement material) to the east sector of

602 the dome. There is evidence of landslides associated probably with the stress regime

603 enhanced by seismicity (Servicio Sismológico Nacional, UNAM;

604 http://www.ssn.unam.mx) and heavy rainfalls with an annual precipitation between 4,500

605 and 5,000 mm (http://www.tapachula.gob.mx). Thus, we assume that we dated the

606 approximate age of a landslide and not the age of the dome extrusion. Dendrochronology

607 and lichenometry confirm the ${ }^{36} \mathrm{Cl} \mathrm{CRE}$ dates with trees ranging between 117 and 164 years

608 and lichen ages of 300 years, respectively. These results show that in situ-produced

609 cosmogenic nuclide dating is useful to provide chronological constraints on active mass

610 wasting processes in volcanic environments. Such a scenario further suggests that a

611 monitoring studio (cameras, seismic stations) of these steep cliffs of the Ardillas dome

612 might be necessary to alert downstream populations of future landslides.

613 A young ${ }^{36} \mathrm{Cl} \mathrm{CRE}$ age $(0.4 \pm 0.1 \mathrm{ka})$ has also been obtained from the "Andesitic lava". 614 Here, samples were collected from the west margin of the lava, which seems to be affected 615 by a small landslide that exhibits a crater-like morphology opened to the west (Fig. 6 and 616 supplement material; samples Tac 16-18). Chronological data from lichenometry (390 617 years) also support the ${ }^{36} \mathrm{Cl} \mathrm{CRE}$ age, demonstrating a consistent young exposure of the 618 sampled area. Given the observations of instability, we suggest that the ${ }^{36} \mathrm{Cl} \mathrm{CRE}$ and 619 lichenometry ages represent the age of a historical collapse likely associated with the 620 phreatic explosion crater present at the base of the large NE-SW landslide that dispersed 621 breccia and pyroclastic deposits atop the lava flow. In this sense, more research must be 622 carried out to determine the exact age of the eruption not reported yet.

\subsection{Refined Holocene volcanic history of TVC and hazards implications}

625 After the ca.15 ka collapse of Tacaná that left a horseshoe-shaped crater, renewed activity 626 ensued andesitic lavas (e.g. ca.12 ka Agua Zarca) that partially filled the collapse 627 depression and crater. At around $10 \mathrm{ka}$, the largest explosive Holocene event of Tacaná 
628

629

630

631

632

633

634

635

636

637

638

639

640

641

642

643

644

645

646

647

648

649

650

651

652

653

654

655

656

657

658

took place with the generation of PDCs that were dispersed radially around the volcano affecting up to the base of the cone (Macías et al 2010). This eruption was produced during open vent conditions (no domes involved atop), ejecting a low altitude eruptive column that was called the Once de Abril ash flow sequence (Macías et al., 2015). At about the same time, another collapse generated the Tuimanj debris avalanche to the north (LimónHernández, 2011) that was smaller than the Agua Caliente debris avalanche. After these volcanic events, Tacaná experienced effusive activity with the emplacement of the "East" lava dome at $9.3 \pm 1.9 \mathrm{ka}$, followed by the extrusion of the "Southwest" and "Northwest" lava domes at $8.6 \pm 1.7 \mathrm{ka}$ and $8.9 \pm 0.9 \mathrm{ka}$ (Fig. 6) that filled the horseshoe-crater as we know it today.

Then, explosive activity took place around the summit of the TVC with at least nine small eruptions: (i) Papales ash flow deposit 1 (8683-8180 cal yr BP) (Macías et al., 2015); (ii) the Chocab pumice flow with charcoal embedded at 7933-7595 cal yr BP (García-Palomo et al., 2006); (iii) a pyroclastic sequence of flows and surges dated at 6998-6400 cal yr BP; (iv) a pyroclastic surge sequence with an underlying paleosol dated at 2920-2715 cal yr BP, (v) a scoria block and ash flow with charcoal dated at 924-748 cal yr BP; and (vi), the phreatomagmatic eruption followed by a sub-Plinian column that dispersed a pumice-rich fallout some 935-748 cal yr BP (Macías et al., 2018), forming an elongated crater lake of $80 \times 60 \mathrm{~m}$ in diameter (Fig. 2). We also report a minimum ${ }^{36} \mathrm{Cl} \mathrm{CRE}$ age of the "Andesitic lava" of $0.4 \pm 0.1 \mathrm{ka}$ that was emitted somewhere close to the Southwest dome. This age is supported by chronological data from lichenometry (390 years). The "Andesitic lava" was disrupted by an elongated explosion crater $(60 \times 25 \mathrm{~m})$ made of breccia and pyroclastic deposits dispersed on the lava flow. Based on its different composition, it is likely that the "Andesitic lava" was emitted before the "Northwest" and "Southwest" domes. The olivinebearing lava and the dome samples display negative trends in $\mathrm{MgO}, \mathrm{Fe}_{2} \mathrm{O}_{3}, \mathrm{CaO}$, and $\mathrm{Al}_{2} \mathrm{O}_{3}$ (Fig. 5b-g), suggesting their magmatic link and fractional crystallization of mafic phases at depth (350 MPa; Mora et al., 2013). Besides, magma mixing between mafic melts and andesitic magmas hosted in the reservoir can produce mafic enclaves (Coombs et al., 2003; Mora et al., 2013); such mixing mechanism is commonly considered as a trigger of volcanic eruptions (Manrique et al., 2020). Furthermore, the young ${ }^{36} \mathrm{Cl} \mathrm{CRE}$ dates 
determined for the Ardillas lava dome $(0.2 \pm 0.1 \mathrm{ka})$ and the "Andesitic lava" flow $(0.4 \pm$

$660 \quad 0.1 \mathrm{ka}$ ) testify the occurrence of active gravitational processes. These processes are related 661 to a NE-SW fissure along which occur tensional fractures, landslide scars, vents of 662 phreatomagmatic and phreatic explosions (e.g. 1986 explosion), hydrothermal fluids, and 663 fumaroles.

664 Three more historical explosive eruptions have been recognized on the slopes of Tacaná 665 volcano. One of them produced a yellow pyroclastic flow deposit dated at 536-157 cal yr 666 BP (Limón-Hernández, 2011). Another one produced an ash flow deposit called the Papales 667 ash flow dated at 496 - To Present cal yr BP (Macías et al., 2015), whereas a white 668 pyroclastic surge deposit was dated at 285 - To Present cal yr BP (Macias et al., 2015). The 669 last events at Tacaná were small explosions that took place during the last two centuries in 670 1855-1856 (Mercado and Rose, 1992; Carlón et al., 2020), 1949 (Müllerried 1951), and 6711986 (De la Cruz-Reyna et al., 1989).

672 The presence of lava domes (ca. $9 \mathrm{ka}$ ) at the Tacaná summit (together with the lava 673 emplaced to the north) infilling the horseshoe-shaped crater suggests that after the ca.15 ka 674 sector collapse (Agua caliente debris avalanche), the activity shifted from explosive to 675 effusive eruptions, lasting for centuries or thousands of years. This is a common 676 phenomenon observed in many volcanoes after a sector collapse (e.g. Popocatépetl, Siebe 677 et al., 2017) probably related to degassing of magma. Furthermore, lava domes represent 678 the location of volcanic conduits from which magma was ejected to the surface. Thus, the 679 summit lava domes of Tacaná volcano emplaced during Early Holocene blocked the 680 volcanic conduit because no other craters are exposed at the summit today. Therefore, the 681 question arises where the vent responsible for the Late to Middle Holocene explosive 682 eruptions is located. A blockage of the conduit in the meantime could prevent the degassing 683 of the magma reservoir producing overpressure and eventually explosive eruptions when 684 the internal pressure reaches the rupture pressure of the surface. This could have produced 685 the nine dated explosive eruptions at the TVC (Macías et al., 2015). The magma 686 accumulated in the reservoir sought other paths to get to the surface as the set of NE-SW 687 fractures observed nowadays (Fig. 4) from which the phreatomagmatic explosion formed a 688 crater-lake around $0.76 \mathrm{ka}$ (Macías et al., 2015), that was drained during the historic 
phreatic explosion of 1949. The study of lava domes has important implications to specify

690 the behavior of eruption style (explosive-effusive) and the generation of block-and-ash

691 flows (i.e.: Colima volcano; Saucedo et al., 2002) that are one of the most dangerous

692 phenomena in explosive events (Vázquez et al., 2019). Explosive eruptions like those dated

693 at 5 and $2 \mathrm{ka}$ (Macías et al., 2015) could be related to the gravitational collapse of the external parts of summit domes and/or lava fronts (Saucedo et al., 2019).

695 We have recognized two NE-SW and two NW-SE scar collapses around the TVC summit.

696 These scar collapses have orientations in agreement with the present stress regime in the 697 area. Geometrically, this suggests that the location and evolution of the TVC could be 698 related to fractures with a $\mathrm{N}^{\circ} \mathrm{E}$ to $\mathrm{N} 75^{\circ} \mathrm{E}$ direction, which are in good agreement with 699 the results of García-Palomo et al. (2006), and could be associated with a large-scale 700 fracture with the same orientation (Fig. 4). Such stress regime and fault system is typical of 701 an active transtensive tectonic environment. Because no primary volcanic deposits are 702 associated with these events (i.e. debris avalanche deposits, or fallout and pyroclastic flow 703 deposits), they likely were produced by gravitational collapses only. The Tacaná summit 704 domes are highly viscous based on their acidic andesitic to dacitic compositions with 705 pronounced steep edges representing unstable parts prone to collapse. In addition, current 706 Google Earth images show active landslides taking place in the eastern portion of Ardillas 707 dome and the northeastern part of San Antonio volcano. This area is affected by the NE708 SW tension fractures displayed in figure 4, which past landslides dated in this study 709 ("Andesitic lava" and Ardillas dome) area associated with it. Therefore, this persistent 710 volcanic activity and mass waste processes highlight the need for a permanent monitoring 711 system of the complex, which would be essential to predict future geologic hazards and 712 mitigate the associated risks for the nearby populations.

713 A better constraint of the eruptive chronology of the Holocene activity of the TVC has been 714 complemented with our results highlighting an intense effusive volcanic and landslide 715 activity during the Holocene. This Holocene volcanic activity of the TVC is similar to other 716 volcanes in Mexico as Colima and Popocatépetl. Colima volcano (the most active volcano 717 in Mexico) has experienced at least nine explosive eruptions intercalated with dome718 forming events (Macías and Arce, 2019), and several small-magnitude eruptions (1991, 

2000, 2002, 2006, 2015) (Rodríguez-Elizarrarás et al., 1991; Saucedo et al., 2005, 2010;

720 Mora et al., 2004; Capra et al., 2016). Popocatépelt volcano has recorded 12 explosive 721 eruptions during the Holocene (Macías and Arce, 2019), involving three large magnitude 722 Plinian eruptions (Siebe et al., 1995; Siebe and Macías, 2006). Therefore, the TVC stands 723 among the most active (hazardous) volcanoes in Mexico during the Holocene. In terms of 724 risk, however, the TVC is the second most dangerous volcano just after Popocatépetl, 725 because a future eruption would threaten more than around 300,000 people, including the 726 city of Tapachula. A Plinian eruption would disrupt life in Central America affecting main 727 cities of Belize, Guatemala, El Salvador, Honduras, and Mexico (Vázquez et al., 2019).

\section{Conclusions}

${ }^{36} \mathrm{Cl} \mathrm{CRE}$ dating, dendrochronology and lichenometry were combined to determine the 730 unknown ages of lava domes, a steep cliff of the late Pleistocene horseshoe-shaped crater, 731 and one lava from Tacaná volcano. The summit lava domes ("East", "Northwest" and 732 "Southwest") are dated consistently at $9.3 \pm 1.9 \mathrm{ka} ; 8.9 \pm 0.9 \mathrm{ka} ; 8.6 \pm 1.7 \mathrm{ka}$, providing 733 evidence of a voluminous effusive activity around $9 \mathrm{ka}$ that followed a major explosive 734 eruption of Tacaná (Once de Abril ash flow sequence).

736 Furthermore, ${ }^{36} \mathrm{Cl} \mathrm{CRE}$ ages of the cliff of the horseshoe-shaped crater of ca. 5-7 ka most 737 likely correspond to gravitiational rock fall events rather than to the collapse event of the 738 crater, which is expected to predate the summit domes according to the volcanic 739 stratigraphy. Strikingly, the combination of ${ }^{36} \mathrm{Cl} \mathrm{CRE}$ ages, lichenometry and 740 dendrochronology in the "Andesitic lava" and Ardillas dome resulted also useful to detect 741 active processes associated with NE-SW landslide scars, explosion craters, phreatic vents, 742 fumarole activity, and tensional fractures all of which are perpendicular to the NW-SE 743 minimum stress regime $(\sigma 3)$ in the area. Therefore, we conclude that Tacaná is one of the 744 most active volcanoes in Mexico, probably the third just after the Colima and Popocatépetl 745 volcanoes. This scenario implies the need for a significant effort to mitigate volcanic 746 hazards and associated risks (i. e. volcanic collapses) that can affect the nearby populations.

\section{Acknowledgements}


This research was supported by Consejo Nacional de Ciencia y Tecnología (CONACyT) projects A1-S-21156 to J. Alcalá Reygosa and PN522 to J.L. Macías. Dirección de Asuntos del Personal Académico (DGAPA-PAPIIT) IN112720 to J.L. Macías, and IN101620 to J.L. Arce. The ${ }^{36} \mathrm{Cl}$ measurements were performed at the ASTER AMS national facility (CEREGE, Aix en Provence) which is supported by the INSU/CNRS, the ANR through the "Projets thématiques d'excellence" program for the "Equipements d'excellence" ASTERCEREGE action and IRD. We are also grateful to Irma Fabiola Mendiola López and Omar López Arevalo (Instituto de Geofísica Unidad Morelia; Universidad Nacional Autónoma de México) whom helped in the physical treatment of the ${ }^{36} \mathrm{Cl}$ samples. We are indebted with J.I. Lara, A. Lugo, M. Mendoza, G. Sosa for sharing field campaings with us at the volcano. We are grateful for the constructive comments by Naki Akcar and Venera R. May whom greatly improved the manuscript.

\section{References}

Alcalá-Reygosa, J., Palacios, D., Schimmelpfennig, I., Vázquez-Selem, L., García-Sancho, L., Franco-Ramos, O., Villanueva, J., Zamorano, J. J., Aster Team (Aumaitre, G., Bourlès, D., Keddadouche, K.) 2018a. Dating late Holocene lava flows in Pico de Orizaba (Mexico) by means of in situ-produced cosmogenic ${ }^{36} \mathrm{Cl}$, lichenometry and dendrochronology. Quaternary Geochronology 47, 93-106. https://doi.org/10.1016/j.quageo.2018.05.011.

Alcalá-Reygosa, J., Arce, J. L., Schimmelpfennig, I., Salinas, E. M., Rodríguez, M. C., Léanni, L., Aster Team (Aumaitre, G., Bourlès, D., Keddadouche, K.) 2018b. Revisiting the age of the Jumento volcano, Chichinautzin Volcanic Field (Central Mexico), using in situ-produced cosmogenic 10Be. Journal of Volcanology and Geothermal Research 366, 112-119. https://doi.org/10.1016/j.jvolgeores.2018.10.005.

Arce, J.L., Macías, J.L., Vázquez-Selem, L. 2003. The 10.5 ka Plinian eruption of Nevado de Toluca, Mexico: stratigraphy and hazard implications. Geological Society of America Bulletin 115, 230-248.

Arce, J.L., Macías, J.L., Gardner, J.E., Rangel, E., 2012. Reconstruction of the Sibinal Pumice, an andesitic Plinian eruption at Tacaná Volcanic Complex, Mexico-Guatemala. Journal of Volcanology and Geothermal Research 217-218, 39-55. https://doi.org/10.1016/j.jvolgeores.2011.12.013. 
Arce, J.L., Walker, J., Keppie, J. D., 2015. Petrology and geochemistry of El Chichón and Tacaná: two active, yet contrasting Mexican volcanoes. In: Active Volcanoes of Chiapas (Mexico): El Chichón and Tacaná. Edited by T. Scolamacchia and J.L. Macías. SpringerVerlag, 25-43 p. https://doi:10.1007/978-3-642-25890-9_2.

783 Arnold, M., Aumaître, G., Bourlès, D. L., Keddadouche, K., Braucher, R., Finkel, R. C., 784 Nottoli, E., Benedetti, L., Merchel, S. 2013. The French accelerator mass spectrometry 785 facility ASTER after 4 years: status and recent developments on ${ }^{36} \mathrm{Cl}$ and ${ }^{129} \mathrm{I}$. Nuclear 786 Instruments and Methods in Physical Research 294, 24-28. 787 https://doi.org/10.1016/j.nimb.2012.01.049.

788 Capra, L., Macías J.L., Cortés, A., Davila, N., Saucedo, R., Osorio-Ocampo, S., Arce, J.L., 789 Gavilanes-Ruíz, J.C., Corona-Chávez, P., García-Sánchez, L., Sosa-Ceballos, G., Vázquez, 790 R. 2016. Preliminary report on the July 10-11, 2015 eruption at Volcán de Colima: 791 Pyroclastic density currents with exceptional runouts and volumes. Journal of 792 Volcanolology and Geothermal Research 310, 39-49. 793 https://doi.org/10.1016/j.jvolgeores.2015.11.022.

Carlon, T., Macías, J.L., Mendoza, M., and Villanueva, J. 2020. Evidence of volcanic 796 activity in the growth rings of trees in the Tacaná Volcano, Mexico-Guatemal. Journal of Canadian Forest 50: 65-72. http://doi.org/10.1139/cjfr-2019-0214.

Coombs, M. L., Eichelberger, J. C., Rutherford, M. J. 2003. Experimental and textural constraints on mafic enclave formation in volcanic rocks. Journal of Volcanology and Geothermal Research 119, 125-144. https://doi.org/10.1016/S0377-0273(02)00309-8.

De la Cruz-Reyna, S., Armienta, M.A., Zamora, V., Juárez, F. 1989. Chemical changes in spring waters at Tacaná Volcano, Chiapas, México. Journal of Volcanolology and Geothermal Research 38, 345-353. https://doi.org/10.1016/0377-0273(89)90047-4.

806 Dunai, T.J., 2010. Cosmogenic nuclides. Principles, Concepts and Applications in the 807 Earth Surface Sciences. Cambridge University Press, pp. 198.

808 Espíndola, J. M., Medina, F. M., and De los Ríos, M., 1989. A C-14 age determination in 809 the Tacaná volcano (Chiapas, Mexico). Geofisica Internacional 28, 123-128.

810 Fink, D., Vogt, S., Hotchkis, M. 2000. Cross-sections for ${ }^{36} \mathrm{Cl}$ from Ti at Ep $=35-150$ 811 MeV: applications to in-situ exposure dating. Nuclear Instruments and Methods in Physical 812 Research Section B Beam Interaction Mater and Atoms 172, 861-866. 813 https://doi.org/10.1016/S0168-583X(00)00200-7. 
815 García-Palomo, A., Macías, J.L., Arce, J.L., Mora, J.C., Hughes, S., Saucedo, R., 816 Espíndola, J.M., Escobar, R., Layer, P. 2006. Geological evolution of the Tacaná Volcanic 817 Complex, México-Guatemala. In: Rose WI, Bluth GJS, Carr MJ, Ewert JW, Patino LC, 818 Vallance JW (eds) Natural Hazards in Central America. Boulder, Colorado. Geological

819 Society of America, Special Paper 412, 39-57. https://doi.org/10.1130/2006.2412(03).

Garduño, V.H., Macías, J.L., Molina, R. 2015. Geodynamic setting and pre-volcanic geology of active volcanism in Chiapas. In: Active Volcanoes of Chiapas (México): El Chichón and Tacaná. Edited by T. Scolamacchia and J.L. Macías. Springer Verlag, 124. DOI 10.1007/978-3-642-25890-9_1.

Jomelli, V., Lane, T., Favier, V., Masson-Delmotte, V., Swingedouw, D., Rinterknecht, V., Schimmelpfennig, I., Brunstein, D., Verfaillie, D., Adamson, K., Leanni, L., Mokadem, F., Aumaitre, G., Bourles, D.L., Keddadouche, K. 2016. Paradoxical cold conditions during the medieval climate anomaly in the Western Arctic. Scientific Reports 6, 32984. http://dx.doi.org/10.1038/srep32984.

Limón-Hernández, C. G. 2011. Estratigrafía y morfología de los flujos de lava y depósitos asociados a la actividad efusiva del volcán Tacaná, México-Guatemala. Master thesis, Posgrado en Ciencias de la Tierra UNAM, México, 125 p.

Macías J. L, Espíndola J. M, García-Palomo A, Scott K. M, Hughes S, Mora J. C 2000. Late Holocene Peléan style eruption at Tacaná Volcano, Mexico-Guatemala: Past, present, and future hazards. Bulleting Geological Society of America 112, 1234-1249.

https://doi.org/10.1130/00167606(2000)112<1234:LHPEAT>2.0.CO;2

Macías, J.L., Arce, J.L., García-Palomo, A., Mora, J.C., Layer, P.W., Espíndola, J.M. 2010. Late-Pleistocene flank collapse triggered by dome growth at Tacaná Volcano, MéxicoGuatemala, and its relationship to the regional stress regime. Bulletin of Volcanology 72, 33-53.

Macías, J.L., Arce, J.L., Layer, P.W., Saucedo, R., Mora, J.C. 2015. Eruptive history of the Tacaná Volcanic Complex. In: Scholamacchia T, Macías JL (Eds.) Active Volcanoes of Chiapas (Mexico) El Chichón and Tacaná, Active Volcanoes of the world, Springer Verlag pp. 115-138.

Macías, J.L., Arce, J.L., Capra, L., Saucedo, R., Sánchez-Núñez, J.M. 2018. Late Formative flooding of Izapa after an eruption of Tacaná volcano. Ancient Mesoamerica 29:361-371. 
853

854

855

856

857

858

859

860

861

862

863

864

865

866

867

868

869

870

871

872

873

874

875

876

877

878

879

880

881

882

883

884

885

Macías, J. L., Arce, J. L. 2019. Volcanic Activity in Mexico During the Holocene. In The Holocene and Anthropocene Environmental History of Mexico (pp. 129-170). Springer, Cham. https://doi.org/10.1007/978-3-030-31719-5_8.

Manrique, N., Samaniego, P., Médard, E., Schiavi, F., Mariño, J., Liorzou, C. 2020. Preeruptive magmatic processes associated with the historical $(218 \pm 14 \mathrm{aBP})$ explosive eruption of Tutupaca volcano (southern Peru). Bulletin of Volcanology, 82:6, https://doi.org/10.1007/s00445-019-1335-4.

Marrero, S. M., Phillips, F. M., Caffee, M. W., Gosse, J. C., 2016. CRONUS-Earth cosmogenic ${ }^{36} \mathrm{Cl}$ calibration. Quaternary Geochronology 31, 199-219. https://doi.org/10.1016/i.quageo.2015.10.002.

Martíni, M., Capaccioni, B., Giannini, L., 1987. Ripresa dell'attivita sismica e fumarolica al Vulcano di Tacaná (Chiapas, Messico) dopo un quarantennio di quiescenza. Estrato da Bollettino del Grupo Nazionale per la Vulcanología, 467-470.

Mercado, R., Rose, W.I. 1992. Reconocimiento geológico y evaluación preliminar de peligrosidad del Volcán Tacaná, Guatemala/México. Geofísica Internacional 31(3): 205237.

Merchel, S., Bremser, W., Alfimov, V., Arnold, M., Aumaître, G., Benedetti, L., Bourles, D.L., Caffee, M., Fifield, L.K., Finkel, R.C., Freeman, S.P.H.T., Martschini, M., Matsushi, Y., Rood, D.H., Sasa, K., Steier, P., Takahashi, T., Tamari, M., Tims, S.G., Tosaki, Y., Wilcken, K.M., Xu, S., 2011. Ultra-trace analysis of $36 \mathrm{Cl}$ by accelerator mass spectrometry: an interlaboratory study. Anal. Bio- anal. Chem. https://doi.org/10.1007/s00216-011-4979-2.

Mora, J.C., Macías, J.L., García-Palomo, A., Espíndola, J.M., Manetti, P., and Vaselli, O. 2004. Petrology and geochemistry of the Tacaná Volcanic Complex, Mexico-Guatemala: Evidence for the last $40000 \mathrm{yr}$ of activity. Geofísica Internacional 43, 331-359.

Mora, J. C., Gardner, J. E., Macías, J. L., Meriggi, L. 2013. Magmatic controls on eruption dynamics of the 1950 yr B.P. eruption of San Antonio Volcano, Tacaná Volcanic Complex, Mexico-Guatemala. Journal of Volcanology and Geothermal Research 262, 134152. https://doi.org/10.1016/j.jvolgeores.2013.06.002.

Müllerried, F.K.G., 1951. La reciente actividad del Volcán Tacaná, Estado de Chiapas, a fines de 1949 y principios de 1950. Informe del Instituto de Geología, UNAM, 28p.

N.O.A.A, 1976. U.S. Standard Atmosphere. US Gov. Print. Off. 
Palacios, L., García-Sancho, Zamorano, J.J., Andrés, N., Pintado, A., 2012. The deglaciation of Iztaccíhuatl volcano (Mexico) from the Little Ice Age maximum to the present, determined by photogrametry and lichenometry. Geophysical Research Abstracts 14, EGU2012-3755 2012.

Rodriguez-Elizarrarás, S., Siebe, C., Komorowski, J. C., Espíndola, J. M., Saucedo, R. 1991. Field observations of pristine block and ash flow deposits emplaced April 16-17 1991 at Volcán de Colima, Mexico. Journal of Volcanology and Geothermal Research 48 (3-4), 399-412. https://doi.org/10.1016/0377-0273(91)90054-4.

Rouwet, D., Taran, Y., Inguaggiato, S., Varley, N. 2004. Hydrothermal activity at Tacaná volcano, Mexico-Guatemala. In: Wanty R, Seal R II (eds) WRI-11. Taylor and Francis Group, London, 173-176.

Rouwet, D., Inguaggiato, S., Taran, Y., Varley, N., Santiago, J.A., 2009. Chemical and isotopic compositions of thermal springs, fumaroles and bubbling gases at Tacaná Volcano (Mexico-Guatemala): implications for volcanic surveillance. Bulletin of Volcanolology 71, 319-335.

Saucedo, R., Macías, J.L., Bursik, M., Mora, J.C., Gavilanes, J.C., Cortes, A. 2002. Emplacement of pyroclastic flows during the 1998-1999 eruption of Volcán de Colima, Mexico. Journal of Volcanology and Geothermal Research 117 (1-2), 129-153. https://doi.org/10.1016/S0377-0273(02)00241-X.

Saucedo, R., Macías, J.L., and Bursik, M.I., 2004. Merapi-type pyroclastic flows produced during the 1991 eruption of Colima Volcano: stratigraphy, sedimentology and emplacement mechanisms. Bulletin of Volcanology 66, 291-306.

Saucedo, R., Macías, J.L., Sheridan, M.F., Bursik, M.I., Komorowski, J.C. 2005. Modeling of pyroclastic flows of Colima Volcano, Mexico: Implications for hazard assessment. Journal of Volcanology and Geothermal Research 139, 103-115. https://doi.org/10.1016/j.jvolgeores.2004.06.019.

Saucedo, R., Gavilanes-Ruiz, J.C., Macías, J.L., Arce, J.L., Komorowski, J.C., Gardner, J., Valdez-Moreno, G., (2010). Eyewitness, stratigraphy, chemistry, and eruptive dynamics of the 1913 Plinian eruption of Volcán de Colima, México. Journal of Volcanology and Geothermal Research, 191: 149-166. https://doi.org/10.1016/j.jvolgeores.2010.01.011.

Saucedo, R.1, Macías, J.L., Gavilanes-Ruiz, J.C., Bursik, M.I., and Vargas-Gutiérrez, V., 2019. Pyroclastic density currents at Volcán de Colima. N. Varley et al. (eds.), Volcán de 
920 Colima, Active Volcanoes of the World, https://doi.org/10.1007/978-3-642-25911-1_4,

921 Chapter 12, 111-140 p.

922 Schimmelpfennig, I., Benedetti, L., Finkel, R., Pik, R., Blard, P. H., Bourle, D., Burnard, 923 P., Williams, A. 2009. Sources of in-situ ${ }^{36} \mathrm{Cl}$ in basaltic rocks. Implications for cali924 bration of production rates. Quaternary Geochronology 4, 441-461. 925 https://doi.org/10.1016/j.quageo.2009.06.003.

926 Schimmelpfennig, I., Benedetti, L., Garreta, V., Pik, R., Blard, P. H., Burnard, P., Bourlès, 927 D., Finkel, R., Ammon, K., Dunai, T. 2011. Calibration of cosmogenic ${ }^{36} \mathrm{Cl}$ production 928 rates from $\mathrm{Ca}$ and $\mathrm{K}$ spallation in lava flows from Mt. Etna ( $38^{\circ} \mathrm{N}$, Italy) and Payun Matru $929\left(36^{\circ} \mathrm{S}\right.$, Argentina). Geochimica et Cosmochimica Acta 75, 2611-2632. $930 \quad$ 10.1016/j.gca.2011.02.013.

931 Schimmelpfennig I, Schaefer J, Putnam A, Koffman T, Benedetti L, Ivy- Ochs S, ASTER 932 Team, Schlüchter C. 2014. ${ }^{36} \mathrm{Cl}$ production rate from K-spallation in the European Alps 933 (Chironico landslide, Switzerland). Journal of Quaternary Science 29, 407-413. 934 https://doi.org/10.1002/jqs.2720.

935 Siebe, C.G., Macías, J.L., Abrams, M., Elizarraras, R.S., Castro, R., Delgado, H. 936 1995. Quaternary Explosive Volcanism and Pyroclastic Deposits in East-Central Mexico: 937 Implications for Future Hazards. In: Chacko, J.J., and Whitney, J.A., (Eds.), Guidebook of 938 Geological Excursions for the 1995 Annual Meeting of the Geological Society of America, 939 New Orleans, Book 1, p. 1-48.

941 Siebe, C., Macías, J.L. 2006. Volcanic hazards in the Mexico City metropolitan area from 942 eruptions at Popocatepetl, Nevado de Toluca, and Jocotitlán stratovolcanoes and 943 monogenetic scoria cones in the Sierra de Chichinautzin Volcanic Field. in Siebe, C., 944 Macías, J.L., and Aguirre-Díaz, G.J., eds., Neogene-Quaternary continental margin 945 volcanism: A perspective from Mexico. Geological Society of America. Special Paper 402, 946 p. 237-252. doi: 10.1130/2006.2402(05).

947 Siebe, C., Salinas, S., Arana-Salinas, L., Macías, J.L., Gardner, J., and Bonasia, R., 2017. 948 The $\sim 23,500 \mathrm{yr}^{14} \mathrm{C}$ BP White Pumice Plinian eruption and associated debris avalanche and 949 Tochimilco lava flow of Popocatépetl volcano, México. Journal of Volcanology and 950 Geothermal Research 333-334, 66-95. https://doi.org/10.1016/j.jvolgeores.2017.01.011.

951 Stone, J., 2000. Air pressure and cosmogenic isotope production. Journal of Geophysical 952 Research 105, 23,753-23,759. https://doi.org/10.1029/2000JB900181. 
953 Stone, J.O., Fifield, K., Vasconcelos, P., 2005. Terrestrial chlorine-36 production from 954 spallation of iron. In: 10th International Conference on Accelerator Mass Spectrometry, 955 Berkeley, USA.

956 Stokes, M.A., Smiley, T.L. 1996. An introduction to tree-ring dating. The University of 957 Arizona Press, Tucson, Arizona.

958

959 Vázquez-Selem, L., Heine, K., 2011. Late quaternary glaciation in Mexico. In: Ehlers, J., 960 Gibbard, P.L., Hughes, P.D. (Eds.), Quaternary Glaciations - Extent and Chronology. A 961 Closer Look. Elsevier, Amsterdam, pp. 849-861. http://doi.org/10.1016/B978-0- 444962 53447-7.00061-1.

963

964 Vázquez, R., Bonasia, R., Folch, A., Arce, J.L., Macías, J.L. 2019. Tephra fallout hazard 965 assessment at Tacaná volcano (Mexico). Journal of South American Earth Sciences 91, 966 253-259. https://doi.org/10.1016/j.jsames.2019.02.013.

967 Vermeesch, P., 2007. CosmoCalc: an excel add-in for cosmogenic nuclide calculations. G968 cubed 8, 1525-2027.

969 Ward, G. K., Wilson, S. R. 1978. Procedures for comparing and combining radiocarbon age 970 determinations: a critique. Archaeometry 20 (1), 19-31. https://doi.org/10.1111/j.1475971 4754.1978.tb00208.x.

972

973

Williams, S. N., Self, S., 1983. The October 1902 Plinian eruption of Santa Maria volcano, 974 Guatemala. Journal of Volcanology and Geothermal Research 16, 33-56. 975 https://doi.org/10.1016/0377-0273(83)90083-5.

976

977

978

979

980

981 
983

984

985

986

987

988

\section{SUPPLEMENTS}



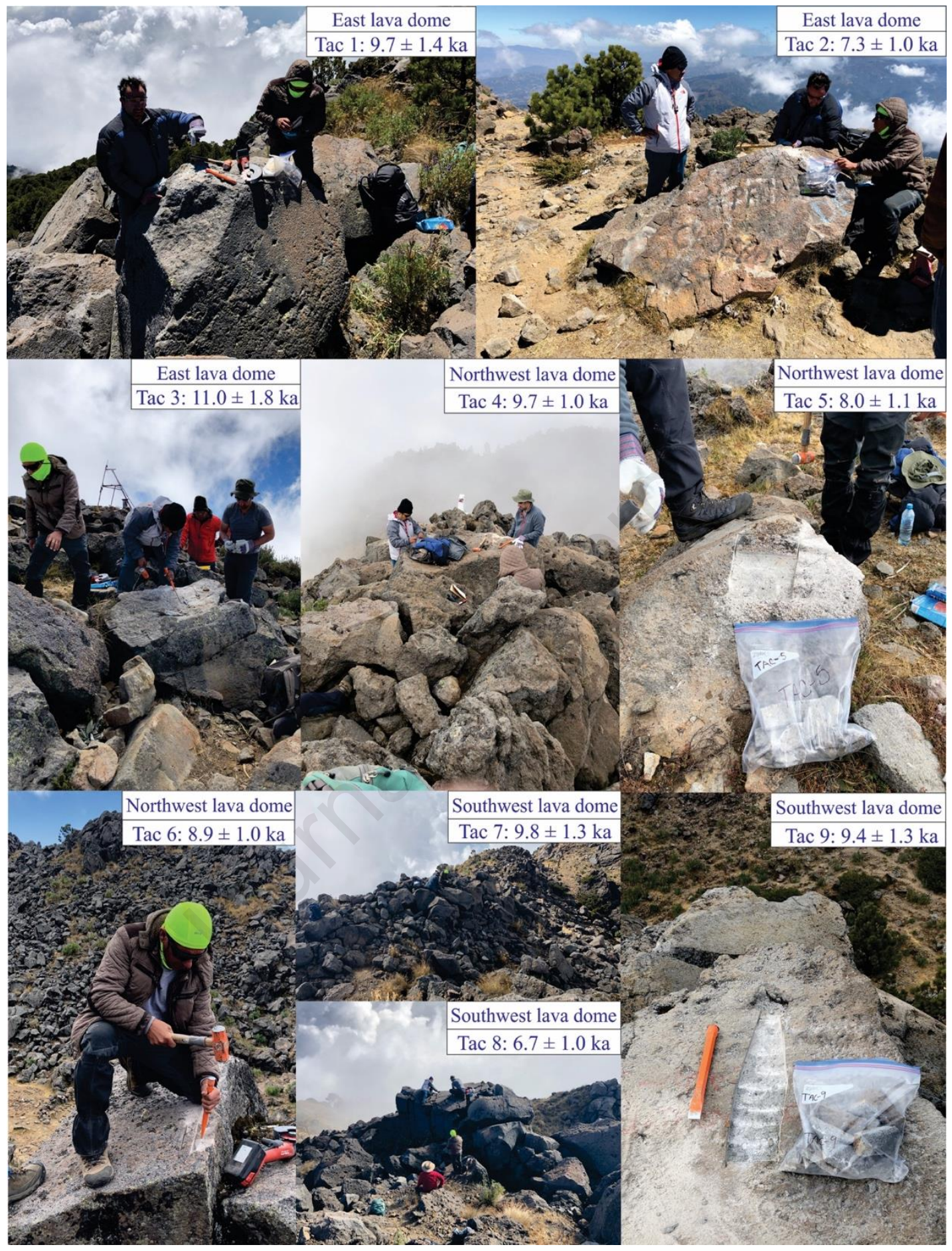

990 Detailed photographs of the samples collected for ${ }^{36} \mathrm{Cl} \mathrm{CRE}$ dating from the summit lava domes of 991 Tacaná volcano.

992

993

994 


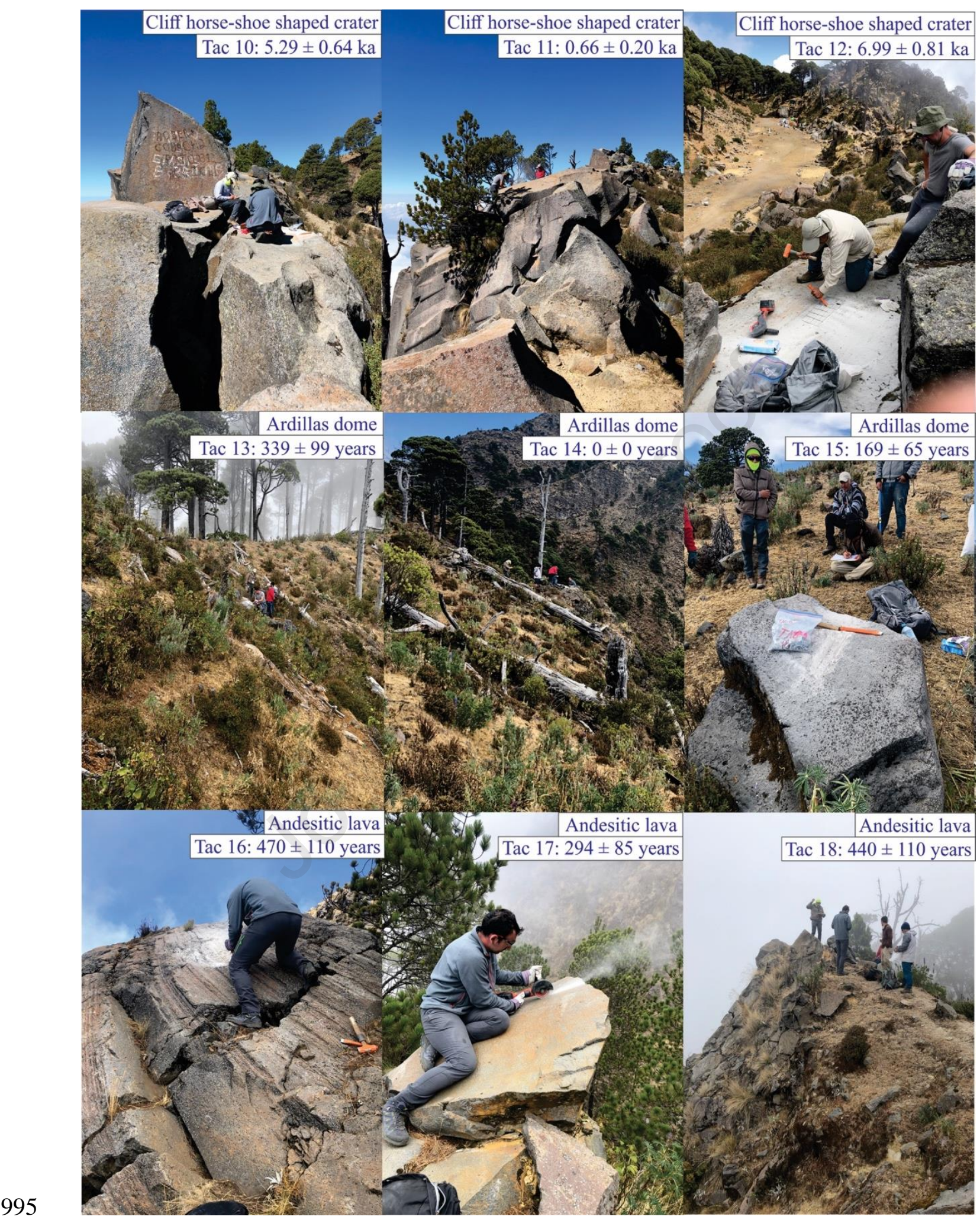

996 Detailed photographs of the samples collected for ${ }^{36} \mathrm{Cl} \mathrm{CRE}$ dating from the cliff collapse scar, the Ardillas dome and the "Andesitic lava" from Tacaná Volcanic Complex. 


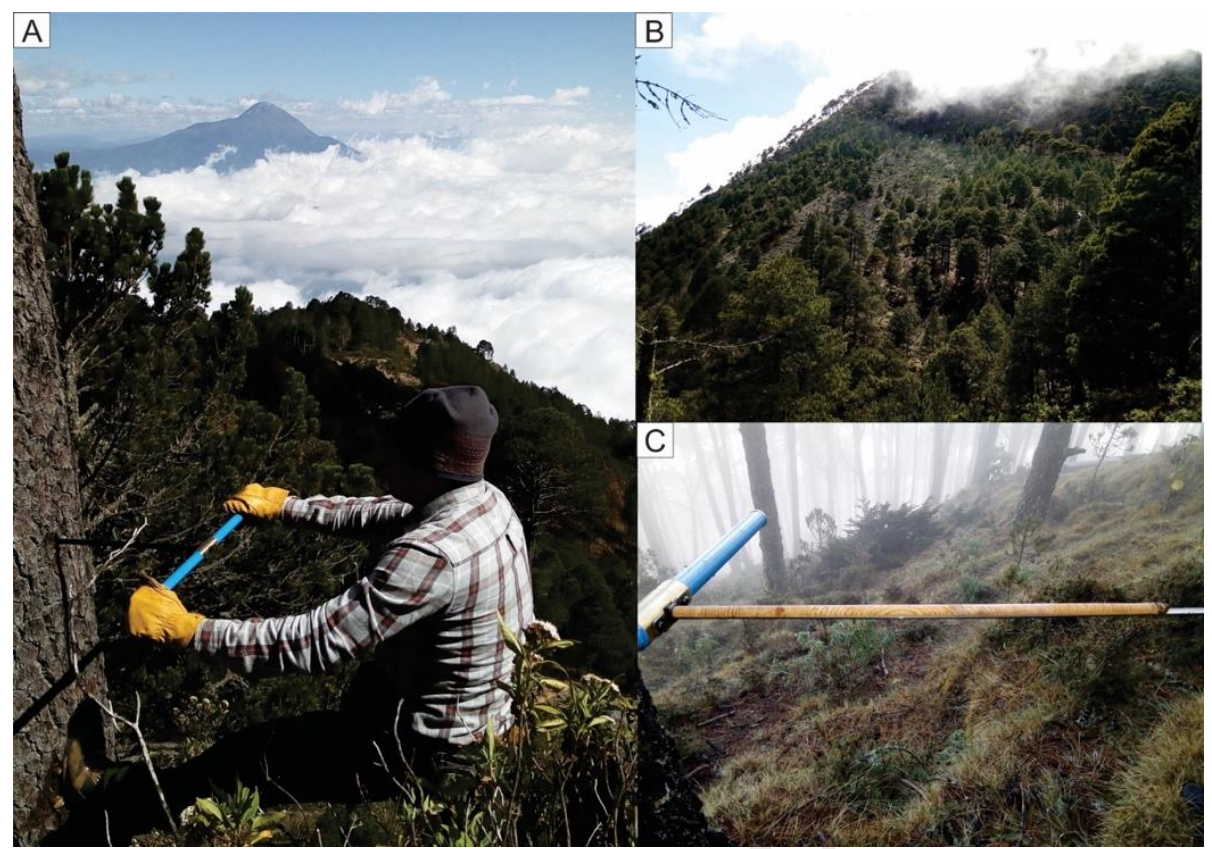

1000 Detailed photographs of the samples collected for dendrochronology. A) Sampling a specimen of 1001 Pinus hartwegii Lindl using a Häglof borer perpendicular to the stem and at breast height; B) Forest 1002 of Pinus hartwegii Lindl that grows on Ardillas dome; C) Detailed of the sample from a specimen 1003 of Pinus hartwegii Lindl. The ages range between 117 to 164 years.

1004

1005

1006

1007

1008 


\section{Declaration of interests}

$\sqrt{ }$ The authors declare that they have no known competing financial interests or personal relationships that could have appeared to influence the work reported in this paper.

$\square$ The authors declare the following financial interests/personal relationships which may be considered as potential competing interests:

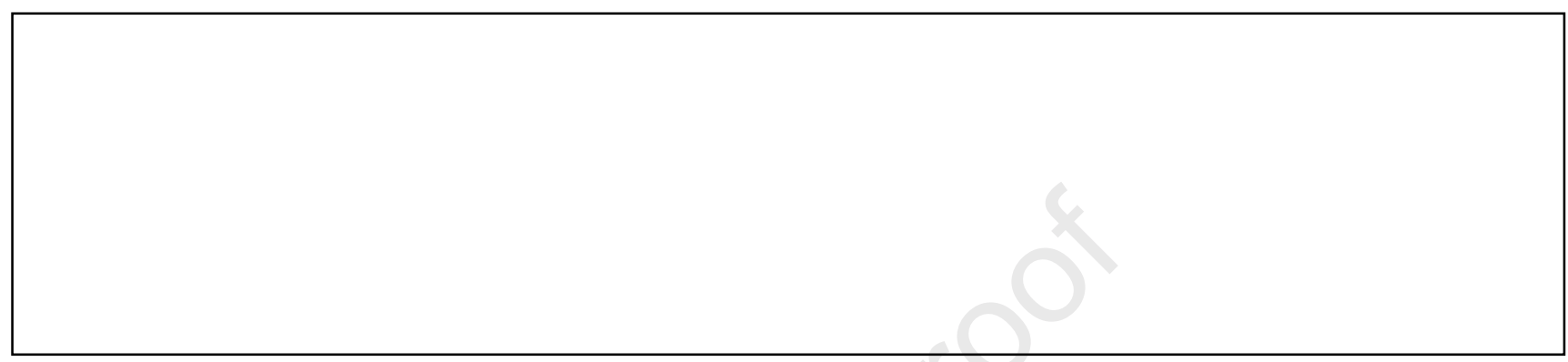

